Anita I. Nagy, Ph.D., Associate Professor

University of Miskolc

Faculty of Law

jognani@uni-miskolc.hu

László L. Dornfeld, Ph.D. Student

University of Miskolc

Faculty of Law

dlaci120@gmail.com

\title{
DEVELOPMENTS OF CERTAIN EU FAIR TRIAL MEASURES AS PART OF THE STOCKHOLM PROGRAMME
}

\begin{abstract}
The principal of mutual recognition in criminal cases is present in EU criminal law since the Framework Decision on the European Evidence Warrant was accepted in 2008. Although the instrument failed to achieve its purpose, the goal of harmonizing cross-border criminal investigations still remains. For the European Investigation Order to succeed a minimum rules in guarantees of fair trials are needed. The European Union recognized this need and the Stockholm Programme was launched in 2009 aiming to realize that. Directives regarding certain suspect rights were accepted since then, including a directive on the right to information and the presumption of innocence. The minimum rules regarding these suspect rights can have a serious impact on national criminal justice systems and their implementation will result in a more harmonised criminal law. These documents were drafted in accordance with the ECHR and the relevant case law of the ECtHR which promises a more enhanced integration of the two major European systems of legislation.
\end{abstract}

Keywords: fair trial measures, Stockholm Programme, the right to information, the presumption of innocence.

Criminal law became the most rapidly developing area of EU cooperation since the Lisbon Treaty, which abolished the highly ineffective third pillar, came 
into effect in December 2009. ${ }^{1}$ As the result of complex institutional changes, mainly the introduction of co-decision procedure, the ratification of the Treaty brought more significant changes to the area of criminal cooperation than to any other areas. ${ }^{2}$ Several policy and legislative changes were needed to properly address the new situation of the post-Lisbon Treaty era.

On a political level the Council of the European Union drafted a Roadmap set out to strengthen the rights of suspects and accused persons throughout the EU in November 2009. ${ }^{3}$ In December the European Council accepted the Stockholm Programme, which was the third multiannual programme on the European Union's Area of Freedom, Security and Justice (AFSJ) and incorporated the Roadmap as a part of the new programme. It was meant to highlight the priorities for the EU institutions on AFSJ cooperation between 2009 and 2014. ${ }^{4}$ In April 2010 an Action Plan to implement the changes was released by the Commission in the form of a communication. ${ }^{5}$ Amongst many things, one of the scopes of the designated period was to create a "Europe of rights" by providing better protection of fundamental rights of suspected and accused people. In June 2014, the Stockholm Programme was joined by a set of strategic guidelines. ${ }^{6}$

Although the significance of EU criminal law in the post-Lisbon system improved greatly, legislation in the area must be made very cautiously. All member states view criminal law as "the last bastion of their sovereignty" which results in a very slow-paced harmonization process. One of the solutions for this problem is to find the similarities in the national legislations and create minimum rules based on that.

The Stockholm Programme decided that EU should accept minimum rules in the area of suspect's rights. As part of this process five Directives were accepted regarding different measures. These were the Translation and Interpretation Directive (measure A), the Right to Information Directive (measure B), the Access to a Lawyer Directive (measure C1), the Presumption of Innocence Directive

${ }^{1}$ Damian Chalmers - Gareth Davies - Giorgio Motti: EU Criminal Law. New York: Cambridge University Press, 2014. p. 583.

${ }^{2}$ Steve Peers: EU Justice and Home Affairs Law. In: The Evolution of EU Law (ed. Paul Craig - Gráinne de Búrca). New York: Oxford University Press, 2011. p. 269.

${ }^{3}$ Roadmap for strengthening procedural rights of suspected or accused persons in criminal Proceedings, RESOLUTION OF THE COUNCIL, of 30 November 2009, (2009/C 295/01)

${ }^{4}$ Sergio Carrera - Elspeth Guild: Does the Stockholm Programme matter? The Struggles over Ownership of AFSJ Multiannual Programming. In: CEPS Papers in Liberty and Security in Europe. CEPS, 2012, ISBN 978-94-6138-253-5 https://www.ceps.eu/system/files/No\%2051\%20 Carrera\%20and\%20Guild\%20on\%20Stockholm\%20Programme.pdf [30.04.2017]

${ }^{5}$ European Commission, Communication, Delivering an area of freedom, security and justice for Europe's citizens: Action Plan implementing the Stockholm Programme, COM(2010) 171 final, Brussels, 20.4.2010.

${ }^{6}$ Conclusions - 26/27 June 2014, http://eujusticia.net/images/uploads/pdf/future-justice2014-06-27-council-strategic-guidelines.pdf [30.04.2017.] 
(measure C2) and lastly the Directive on procedural safeguards for children who are suspects or accused persons in criminal proceedings.

In this paper we would like to focus on two of these EU legal instruments: the Right to Information Directive and the Presumption of Influence Directive. Our main goal is to determine how these affect the protection of the rights of suspects and their relationship with existing European fundamental rights protection measures (mainly the European Charter and the ECHR).

\section{THE RIGHT TO INFORMATION IN DIRECTIVE (EU) 2012/13/EU}

The Directive (EU) 2012/13/EU on right to information in criminal proceedings was the second legal instrument accepted as part of the Stockholm Progamme's agenda of better protection of suspected and accused people's procedural rights on 22 May 2012. It was to be transposed into domestic law by 2 June 2014.

This measure governs the suspect's right to be informed about his procedural rights, about the charges against him and to have access to the case file and materials in the case. The issue of the right to information has received less attention in case law and practitioner training than the previous Directive's scope of right to access to a lawyer, and the Right to Information Directive clarifies these important protections.

The Directive builds heavily on rights protected by Articles 6, 47 and 48 of the Charter of Fundamental Rights of the European Union (the Charter), Articles 5 and 6 of the European Convention for the Protection of Human Rights and Fundamental Freedoms (the ECHR). During the adoption of the Directive EU institutions relied heavily on the case law of the European Court of Human Rights (ECtHR), and therefor there is an opinion that its main function is to articulate those standards as codified norms. ${ }^{7}$

\subsection{Main contents of the Directive}

The right to information is considered to be a crucial aspect of the overall right to defend oneself. While authorities in some member states provide clear information to suspects about their rights whilst in police custody, others provide little or nothing at all. ${ }^{8}$

\footnotetext{
${ }^{7}$ Libby McVeigh - Alex Tinsley: Roadmap Practitioner Tools: Right to Information Directive. p. 6 .

https://www.fairtrials.org/wp-content/uploads/Right-to-Info-Toolkit-FINAL1.pdf [30. 04. 2017.]

${ }^{8}$ Jacqueline S. Hodgson: Safeguarding Suspects' Rights in Europe A Comparative Perspective. New Criminal Law Review: An International and Interdisciplinary Journal, Vol. 14, No. 4 (Fall 2011), p. 649.
} 
Many other problems were identified by professionals regarding right to information in the past few years. Notifications of procedural rights are often written in a very technical language with excessive use of legal terminology which can prove too difficult to be understood by many accused persons. The notification regarding right to silence is often worded in a manner to make it sound unattractive and is some cases draws attention to negative consequences of invoking them. In many cases the suspects are first questioned as a witness and therefore not informed of their rights. Lastly these can result in a waiver of rights without the suspect's proper understanding of the decision's consequences and can seriously harm the fairness of trial. ${ }^{9}$

It must also be noted that before the Directive was drafted, many aspects of the right to information was not established by national laws. For instance the right to remain silent was not statutory in France and Belgium, while the right to have access to the file was not provided for on behalf of the suspect in legislation in Estonia, France, Germany and Spain. ${ }^{10}$

\section{Article 1: Subject}

This Article lays down minimum rules concerning the right to information of suspects and accused persons in relation to their rights in criminal proceedings and to the accusation against them. These rules also apply to persons who are subject to a European Arrest Warrant.

\section{Article 2: Scope}

The rules specified in the Directive must be applied in criminal proceedings from the time when a person is made aware of the competent authorities that he is suspected or accused of having committed a criminal offence until the conclusion of the proceeding. The Article defines the conclusion as the determination of guilt and also sentencing and the resolution of any appeal. As stated in Recital 16 states, the Directive should be applied to every suspected and accused person irrespective of their legal status, citizenship or nationality.

In member states where minor offences are sanctioned administratively, such as in case of large scale traffic offenses, and only the appeal takes place before a court, the Article provides that the Directive should only be applied to the proceedings before the court.

The ECtHR found it a violation of Chapter 6 of ECHR to hear a person as a witness when objectively they are suspected to be involved in committing the crime because in this case an incriminating statement can be produced without the person being informed about their rights (Brusco v. France, App. no. 1466/07

${ }^{9}$ Ibid. p. 14.

${ }^{10}$ Laurens van Puyenbroeck and Gert Vermeulen: Toward Minimum Procedural Guarantees for the Defence in Criminal Proceedings in the EU. The International and Comparative Law Quarterly, Vol. 60, No. 4 (October 2011) p. 1032. 
(Judgment of 14 October 2010). Although the Directive fails to address this situation and Recitals 19 and 28 make it clear that it is intended to be applied "at the latest before their first official interview by the police or another competent authority" as other authors state, the Directive is to be interpreted in line with the ECHR. ${ }^{11}$ This is also enforced by the non-regression clause stated in Article 10.

\section{Article 3: Right to information about rights}

Article 6 (1) and (3)c of the ECHR protects the suspected people's right to silence and legal assistance and in many cases the ECtHR ruled in its judgments that proper information should be provided for these persons regarding their procedural rights. In Aleksandr Zaichenko v. Russia (Judgment of 18 February 2010) the ECtHR ruled that "charge" may be described as official notification of an individual by the competent authority that they have allegedly committed a criminal offence. The case law of the Court also gives protection in cases when the person is not formally accused but is first questioned as a witness by the authorities despite their suspicions. ${ }^{12}$

If the suspects can't invoke their rights due to lack of information by competent national authorities, the criminal proceeding against them can't be seen as fair. In one case, the Court addressed that a waiver of right can be accepted if it is made voluntarily but it is also required to be a "knowing and intelligent relinquishment of a right" (Saman v. Turkey, App. no. 35292/05 (Judgment of 5 April 2011), para. 32.).

However if the waiver is a result of lacking information of the suspect, it can't be seen as effective. The factors that have to be taken in account when deciding that such conduct is a breach of fairness or not, can vary greatly. Some of the criteria in the current ECtHR case law is objective, while others are subjective. ${ }^{13}$ It is important that the caution be given in a language that the suspect understands (Saman v. Turkey, para. 35). The circumstances of the caution must also be taken in account when deciding the effectiveness of a relinquishment. In a case the Court ruled that "it was unlikely that a mere caution in the words provided for in the domestic law would be enough to enable him to sufficiently comprehend the nature of his rights" (Panovits v. Cyprus, para. 74.).

${ }^{11}$ Libby McVeigh - Alex Tinsley p.

12 Alexandros Tsagkalidis: Directive 2012/13/EU on the Right to Information in Criminal Proceedings. Online: http://www.era-comm.eu/procedural_safeguards/kiosk/pdf/2017/Article_ Right_to_Information.pdf [30.09.2017.]

${ }^{13}$ The weight of subjective factors must be determined for each case individually. The young age of the suspect, his lack of literacy or drug dependency can affect whether the caution fulfils the requirements for waiver of right or not. See for example Panovits v. Cyprus, App. no. 4268/04 (Judgement of 11 December 2008) para. 67; Kaciu and Kotorri v. Albania, Apps. nos. 33192/07 and 33194/07 (Judgment of 25 June 2013), para. 120; and Pishchalnikov v. Russia, App. no. 7025/04 (Judgment of 24 September 2009), para. 80. 
Article 3(1) of the Directive provides that suspected and accused people are to be provided promptly orally or written information about certain procedural rights specified by the Article. These are:

(a) the right of access to a lawyer;

(b) any entitlement to free legal advice and the conditions for obtaining such advice;

(c) the right to be informed of the accusation, in accordance with Article 6;

(d) the right to interpretation and translation;

(e) the right to remain silent.

The next paragraph determines that the aforementioned information should be given in simple and accessible language and that the authorities should take into account any particular needs of vulnerable suspects or accused persons. The latter instruction can be seen as a general provision on subjective criteria which, as we could see, already is present in the case law of ECtHR.

\section{Article 4-5: Letter of Rights on arrest}

As the Commission stated in its press release in relation to the Directive, 8 million criminal proceedings takes place in the EU annually. The chance that suspects will be ill-informed about their defence rights is varying across the Member States and in many cases the suspects are only informed about their rights orally, in a technical and incomprehensible language, or not at all. ${ }^{14}$

Due to these tendencies, the Directive provides that suspects and accused that are arrested or detained shall be provided with a Letter of Rights, a written information sheet about their rights already determined in Article 3. This solution is not a new one, as its use was already suggested to Member States by the European Commission's Green Paper in 2003. ${ }^{15}$

The Letter of Rights should also contain information about other rights' application under the national law such as:

(a) the right of access to the materials of the case;

(b) the right to have consular authorities and one person informed;

(c) the right of access to urgent medical assistance;

(d) the maximum number of hours or days suspects or accused persons may be deprived of liberty before being brought before a judicial authority.

${ }^{14}$ Fair trial rights: EU governments endorse law ensuring suspects' right to information in criminal proceedings. Brussels, 3 December 2010. http://europa.eu/rapid/press-release_IP-101652_en.htm?locale=en [30.04.2017.]

${ }^{15}$ European Commission, Green Paper on Procedural Safeguards for Suspects and Defendants in Criminal Proceedings throughout the European Union, COM(2003)75 final, Brussels, 19 February 2003, section 8.1. 
The paper should also contain some basic information about challenging the lawfulness of the arrest, obtaining a review of the detention and making a request for provisional release.

The factors determined by previous ECtHR case law about the proper form and conditions of information should also apply for this information paper. One such aspect specified by the Article that the Letter of Rights shall be drafted in simple and accessible language. It is also provided in the Article that Member States authorities must ensure that the suspect receives the Letter of Rights written in a language that they understand.

Article 5 provides that if the suspect is arrested because of a European Arrest Warrant against him, the Letter of Rights should contain information on their rights according to the law implementing Framework Decision 2002/584/JHA in the executing member state.

The Commission stated that it hopes, the Letter of Rights will help to avoid miscarriages of justice and reduce the number of appeals, while hoping that the efficiency of judicial systems will improve. ${ }^{16}$

\section{Article 6: Right to information about the accusation}

The requirement for notification of the accusation has a strong connection with the notification of rights as being accused is one of the cases after which the provisions of the Directive must be applied. This is also that phase of the criminal proceedings when persons can decide their defence and whether they want to invoke certain rights, such as the right to remain silent, or they wish to waiver them.

Articles 5(2), 6(3)a and $\mathrm{b}$ of the ECHR already addresses this topic. The former provides that arrested persons shall be informed about the reasons for arrest and the criminal charges against them. The latter is about minimum rights for every accused person, which is being informed about the nature and cause of the accusation against him and having adequate time and the facilities for the preparation of defence.

The ECtHR already has many decisions on the conformity of information about the accusation. Over the years the Court has adopted a principle regarding Article 6(3)a which is aimed at guaranteeing a right of information for the defendants at all stages of the criminal process. This specifies that the accused should be informed about both the factual and legal basis for the procedure as particulars of an offense play a crucial rule (Pélissier and Sassi v. France, App. no. 25444/94 (Judgment of 25 March 1999), para. 51-52.). This also includes the legal classification of the facts. ${ }^{17}$ It was also clearly stated that is not enough for the relevant

\footnotetext{
${ }^{16}$ Ibid.

${ }^{17}$ McVeigh - Tinsley, p. 26.
} 
authorities to provide information when requested to do so (Mattoccia v. Italy, App. Judgment of no. 23969/94 (5 July 2000), para. 65.).

Even if the written order properly addresses the relevant legal provisions, it can violate the ECHR without containing any factual circumstances (Fox and others v. United Kingdom, App. no. 12244/86 (Judgment of 30 August 1990), para. 40.). Subjective factors must also be taken in account, as in one case it was ruled to be a violation of the Article to question a deaf, mute and illiterate suspect using an official sign language interpreter as he was not familiar with that form of sign language (Z.H. v. Hungary, App. no 28973/11 (Judgment of 8 November 2012), para. 42-43.).

The Directive's provisions heavily resemble the factors laid down by the case law of the ECtHR. According to Article 6 suspected and accused persons shall be provided promptly with information about the criminal act they are suspected or accused of having committed. Paragraph 1 of the Article states that the information shall be detailed enough which is given a more detailed explanation is Recital 27. It states that the person shall be given all necessary information to prepare their defence. According to Recital 28 the information given should contain the time and place of the criminal act. Obligation under Paragraph (2) is similar to that of the Article 5 (2) of the ECHR. One big difference however is that the latter requires that the suspected and arrested person be provided information "promptly" which is omitted from the Directive. ${ }^{18}$

As provided by Paragraph (3) not only factual information but also the nature and legal classification of the criminal offence, as well as the nature of participation by the accused person. Paragraph 4 also reflects existing ECtHR case law (Juha Nuutinen v. Finland, App. no. 45830/99 (Judgment of 24 April 2007), para. 30-32.) in provisioning that authorities have to provide information about reclassifications of the offence so that the suspected or accused person can plan his defence accordingly.

\section{Article 7: Right of access to the materials of the case}

At the time of the first questioning of the suspect it is not uncommon that neither the suspected nor his lawyer has no access to case files which could affect his decision about certain rights. In some member states access to the files can be restricted by law or by exceptional power of prosecutors which can violate the equality of arms principle. ${ }^{19}$

Articles 6(3)(a), (b) and (c) of the ECHR has connections with this issue although not explicitly but the ECtHR was vocal about in a number of judgments.

${ }^{18}$ Ed Cape: Transposing the EU Directive on the Right to Information: A Firecracker or a Damp Squib? Criminal Law Review. No. 1 (2015), p. 53.

${ }^{19}$ McVeigh - Tinsley, p. 32. 
There is an ongoing debate about the Court's opinion about the counsel's ability to obtain case files before the first questioning of his defendant. There are some vague expressions in these judgements which can be interpreted to support this claim but this is an opinion not shared by other courts. ${ }^{20}$

The ECtHR also addressed that in accordance with the provisions of Article 6(3)(b) access to case files have to be provided for the accused person in a timely manner before trial (Beraru v. Romania, App. no. 40107/04 (Judgement of 18 March 2014), para. 69-70). If the inspection of these files is restricted to the lawyer of the defendant it is not considered as a violation of the Article (Kremzow v. Austria, App. no. 12350/86 (Judgment of 21 September 1993), para. 52). It was also determined by the Court that the time frame for the counsel to review the files should be determined according to the number of pages it consists of (Öcalan v. Turkey, App. no. 46221/99 (Judgment of 12 May 2005), para. 142).

Article 7 of the Directive also addresses many of these concerns. Paragraph 1 provides that in case of arresting a person, the documents which are essential to challenge the decision are made available for him. The next Paragraph is about the availability of material evidence in possession of the competent authority. As stated in Paragraph 3 access to the aforementioned materials have to be granted in a due time to allow the effective exercise of the rights of the defence. Paragraph 4 of the Article determines when a request to access certain files can be refused by authorities. A request can be refused if:

- it would lead to a serious threat $t$ life or fundamental rights of another person

- if such refusal is strictly necessary to safeguard an important public interest (could prejudice an ongoing investigation or could harm the national security) A decision to refuse a request must be made by a judicial authority or be subject to judicial review. This Paragraph is also in line with existing ECtHR case law as it also accepted a public interest immunity principle similar to that of the Directive's. $^{21}$

Lastly it is provided $n$ Paragraph 5 that access to files must be free of charge. Although technically free, defendants can only hold copies of the documents and in case of large files, the cost of photocopying can be significant. In our opinion one effective solution to reducing cost is to allow electronic copies to be given to the defendant. Paragraph 70/B. (11) of the Criminal Procedure Code of Hungary (Act XIX of 1998) allows for accused person or their legal counselor to request an electronic copy of case files. It also provides that if the files are available in electronic formation the copies must be presented on electronic data carriers. The only downside of electronic formation is that the Code does not accept it as authentic.

\footnotetext{
${ }^{20}$ For more detailed information see McVeigh - Tinsley, p. 33-34.

${ }^{21}$ Laurens van Puyenbroeck and Gert Vermeulen: p. 1024.
} 


\section{THE PRESUMPTION OF INNOCENCE AND OF THE RIGHT TO BE PRESENT AT TRIAL IN CRIMINAL PROCEEDINGS IN DIRECTIVE (EU) 2016/343}

On 9 March 2016, the European Parliament and the Council adopted Directive (EU) 2016/343 on the strengthening of certain aspects of the presumption of innocence and of the right to be present at trial in criminal proceedings.

The Directive is the fourth legislative measure that has been passed since the adoption of the Council's Roadmap on procedural rights for suspects and accused persons in 2009.

The presumption of innocence and the right to a fair trial are enshrined in Articles 47 and 48 of the Charter, Article 6 of the ECHR, Article 14 of the International Covenant on Civil and Political Rights (the ICCPR) and Article 11 of the Universal Declaration of Human Rights.

After the Directives regarding the three previous measures, this new Directive tries to enhance the right to a fair trial through the adoption of common minimum rules on certain points of the presumption of innocence and the right to be present at trial. This should result an increased trust between the Member States (MS) in the field of criminal justice and thereby it facilitate mutual recognition.

The first three measures on the basis of the Roadmap were adopted within a rather short time frame: Directive 2010/64/EU on the right to interpretation and translation (measure A) was adopted on 20 October 2010; Directive 2012/13/EU on the right to information (measure B) was adopted on 22 May 2012; and Directive 2013/48/EU on the right of access to a lawyer (measure C1) was adopted on 22 October 2013.

The European Commission has been examining the presumption of innocence for a long time. A Green paper on the presumption of innocence ${ }^{22}$ from 2006 already indicated that the Commission was willing to include the presumption of innocence in a legislative instrument, if there was a need to do so. Although the presumption of innocence was not one of the measures covered by the 2009 Roadmap, Point 2 of this Roadmap made clear that proposals on other topics could be launched. Therefore in November 2013, the Commission presented a package of three further measures to complete the rollout of the Roadmap, as integrated in the Stockholm programme: a proposal for a Directive on provisional legal aid (measure C2), a proposal for a Directive on procedural safeguards for children (measure E), and a proposal for a Directive on the presumption of innocence (the "example" of the Stockholm programme). Article 6(3) of the Treaty on European

\footnotetext{
${ }^{22}$ Proposal for a Directive of the European Parliament and of the Council on the strengthening of certain aspects of the presumption of innocence and of the right to be present at trial in criminal proceedings Brussels, 27.11.2013 COM(2013) 821 final 2013/0407 (COD)
} 
Union (TEU) provides that fundamental rights, as guaranteed by ECHR and as they result from the constitutional traditions common to the Member States, constitute general principles of EU law.

\subsection{Description of the main contents of the Directive}

The approach of the new Directive is rather broad as it addresses not only the presumption of innocence and the connected rights such as the right to remain silent, but it equally addresses the right to be present at one's trial. The new rules apply to all people suspected or accused in criminal proceedings.

\section{Article 1: Subject}

Article 1 confirms that the Directive is intended to lay down minimum rules on "certain aspects of the right to the presumption of innocence in criminal proceeding" and the right to be present at the trial in criminal proceedings. The Directive is not intended, therefore, to be an exhaustive study of the principle and the ECHR will still be the main guide to those aspects which are not included in the text.

\section{Article 2: Scope}

The Directive applies to suspects or accused persons in criminal proceedings from the very start of the criminal proceedings, even before the time when the suspects are made aware by the competent authorities of the fact that they are suspected or accused of having committed a criminal offence. It applies until the conclusion of such proceedings, until the final judgement is delivered.

The right to be presumed innocent encompasses different needs and degrees of protection regarding natural persons and legal persons, as recognized in the case law of the Court of Justice on the right not to incriminate one-self. This Directive takes into account these differences and therefore only applies to natural persons.

\section{Article 3: Presumption of innocence}

Article 3 basically repeats Article 6(2) ECHR and Article 48(1) of the EU-Charter: suspects and accused persons should be presumed innocent until proven guilty according to law.

Article 3 is a simple restatement of the principle. It sets out that "Member States shall ensure that suspects and accused persons are presumed innocent until proven guilty according to law". There is no attempt to articulate the nature of the provision further or set out the core aspects of the presumption for the purposes of the Directive. 


\section{Article 4: Public references to guilt}

The ECtHR established as one of the basic aspects of the principle of presumption of innocence the fact that a court or public official may not publicly present the suspects or accused persons as if they were guilty of an offence if they have not been tried and convicted of it by a final judgment (Minelli v. Switzerland, App. no. 8660/79 (Judgment of 17 December 1980)). According to the case law of the ECtHRthis principle should furthermore apply to all public authorities (Allenet de Ribemont v. France, App. no. 15175/89 (Judgment of 10 February 1995)).

Article 4(3) explained a general exception: the obligation not to refer to suspects or accused persons as being guilty should not prevent public authorities from publicly disseminating information on the criminal proceedings, if this is strictly necessary for reasons relating to the criminal investigation. This could be the case, for example, when video material is released and the public is asked to help in identifying the alleged perpetrator of the criminal offence. ${ }^{23}$

\section{Article 5: Presentation of suspects and accused persons}

According this article, "Member States shall take appropriate measures to ensure that suspects and accused persons are not presented as being guilty, in court or in public, through the use of measures of physical restraint."

It means that the competent authorities should also abstain from presenting suspects or accused persons in court or in public while wearing prison clothes, so they are required to avoid giving the impression that those persons are guilty.

\section{Article 6: Burden of proof}

Article 6 deals with the burden of proof. It requires Member States to "ensure that the burden of proof in establishing the guilt of suspects and accused persons is on the prosecution". This is an important issue. The burden of proof refers to the fact that it is the prosecution who must prove the case against the accused. The initial draft of Article 6 initially contained an article permitting the burden of proof to be shifted to the defence. The European Parliament's Civil Liberties Committee successfully proposed an amendment deleting this provision on the shift of the burden of proof. This Article reflects the ECtHR principle ${ }^{24}$ which is considered as a correct balance between the protection of public interests (the needs of prosecution) and the right of the defence.

\footnotetext{
${ }^{23}$ Steven Cras and Anze Erbeznik: The Directive on the Presumption of Innocence and the Right to Be Present at Trial, Eucrim 1/2016, p. 29.

${ }^{24}$ See, inter alia, ECtHR cases Salabiaku v. France, App. no. 10519/83 (Judgment of 7 October 1988), Barberà, Messegué and Jabardo v. Spain, Telfner v. Austria, App. no. 33501/96 (Judgment of 20 March 2001)
} 


\section{Article 7: Right to remain silent and right not to incriminate oneself}

Article 7 provides that the suspect has the right to remain silent "in relation to the offence that they are suspected or accused of having committed". This should surely have been extended to the right to silence in relation to the commission of any offence.

The right to remain silent and the right not to incriminate oneself are not specifically mentioned in the ECHR, but the ECtHR has derived these rights from the right to a fair procedure under Article 6 of ECHR (Funke v. France, para. 44).

The Commission defined the right to remain silent and the right not to incriminate oneself as absolute rights, which means that they can be exercised without any conditions or qualifications and that there are no negative consequences attached to the exercise of these rights. ${ }^{25}$

Suspects or accused persons should be promptly informed of their right to remain silent according to Directive 2012/13/EU. Such information should also refer to the content of the right to remain silent and of the consequences of renouncing to it and of invoking it.

Article 7(3) notes that "the exercise of the right to remain silent and of the right not to incriminate oneself shall not be used against a suspect or accused person and shall not be considered as evidence that the person concerned has committed the offence which he or she is suspected or accused of having committed". This has to be welcomed and appears to go further than the ECtHR which has found that an accused's decision to remain silent throughout criminal proceedings may carry consequences, such as 'adverse inferences' being draw from the silence.

\section{Artice 8 and 9: Relating to the right to be present at the trial and the right to a new trial}

The provisions regarding trials in absentia, which the Commission had proposed in paragraphs 2 and 3 of Article 8, were more problematic. Here, the Commission had almost copy-pasted provisions from Framework Decision 2009/299/ JHA on trials in absentia.

The ECtHR has confirmed that this is implicit in the right to a fair trial by way of a public hearing (Jacobsson v. Sweden, App. no. 16970/90 (Judgment of 19 February 1998)) and that it is difficult to see how anyone can exercise their defence rights without being present at their own trial. ${ }^{26}$

The Directive has brought clarity on an important point. In fact, in the Framework Decision it was not clear whether in respect of suspects or accused persons whose location is unknown a trial in absentia could be held and whether the resulting

${ }^{25}$ Steven Cras and Anze Erbeznik: p. 31.

${ }^{26}$ Debbie Sayers: The new Directive on the presumption of innocence: protecting the 'golden thread' http://eulawanalysis.blogspot.de/2015/11/the-new-directive-on-presumption-of.html [30.04.2017.] 
decision, including a custodial sentence, could be enforced immediately, in particular if the person concerned has been apprehended.

However important conditions have to be applied. Firstly, Member States may only use the possibility to hold a trial in absentia if they have undertaken "reasonable efforts" to locate the suspects or accused persons. Secondly, the Member States must inform those persons, in particular upon being apprehended, of the decision taken in absentia as well as of the possibility to challenge this decision and the right to a new trial or other legal remedy. ${ }^{27}$

Article 9 establishes a remedy (established by the ECtHR) in cases where the right to be present at trial has not been observed. In this case it is an obligation to provide for a re-trial (Colozza v. Italy, App. no. 9024/80 (Judgment of 12 February 1985)).

\section{CONCLUSION}

The Stockholm Programme was right when determining that fair trial and the right to defence does not only mean the right to access lawyer but has many other dimensions to it, covered by the measures of the programme. To create an efficient system of suspect's rights, it is important to have a balance and appropriate timing to them. Presumption of innocence is a crucial principle to allow a fair trial but it needs other measures to be realized in practice. Without the access to interpretation and translation, the right to information can be meaningless. Even if the suspected or accused person is informed about their rights, they probably can't decide a proper defence strategy without a help from a legal counsel.

As we could see, both Directives build heavily on existing ECHR regulations and ECtHR case law regarding that. The system created by the Convention and the Court has serious limitations in their mechanism as it is not generally observed in all cases. EU level action can force the Member States to adopt the same level of protection for every proceeding. ${ }^{28}$ The realisation of EU legislation on this basis is certainly a move towards enhancing integration between the two major European systems of human rights protection. Continuing this process could create a more complete and effective European human rights protection system, which is realised especially in terms of guarantees and of judicial protection. ${ }^{29}$

${ }^{27}$ Steven Cras and Anze Erbeznik: p. 33.

${ }^{28}$ T.N.B.M Spronken and D.L.F. de Vochtf: EU Policy to Guarantee Procedural Rights in Criminal Proceedings: "Step by Step". 37 North Carolina Journal of International Law and Commercial Regulation (2011-2012), p. 483.

${ }^{29}$ Stefania Negri: Realising a European Area of Justice through Harmonised Protection of Procedural Rights and Enhanced Integration between the EU and the ECHR Legal Systems. 2014, Conf. Int'l Dr. p. 103. 
Др Анитиа И. Нађ, ванредни иррофесор

Универзийети у Мищколиу

Правни факулиетеи

jognani@uni-miskolc.hu

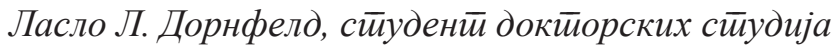

Универзитиети у Мищкколиу

Правни факулиетеи

dlaci120@gmail.com

\section{Развој одређених мера везаних за правично суђење у Европској унији као део Стокхолмског програма}

Сажеейак: Принцийи заједничке сарадње у кривичним йосииуйцима иррисуйни су у кривичном ирраву Евройске уније од оквирне одлуке Евройског̄ доказног̄ налог̄a йрихваћене 2008. гоодине. Иако инсиируменй није усиеео йостиићи своју сврху, и даље остиаје ичиљ хармонизачија иррекогрраничних

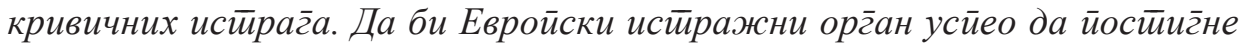
минимална ирравила у гаранцијама йравичних суђења су йойребна су йравила. Евройска унија је йрейознала ову йойребу и Сйокхолмски йрогррам је

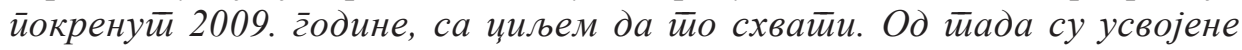

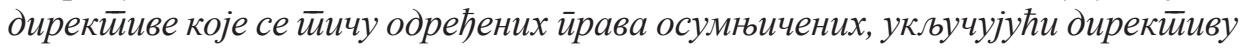

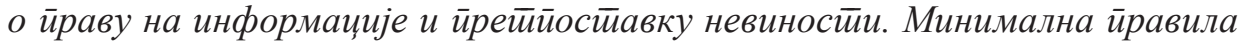

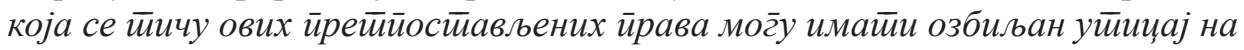
националне сисиете кривичног ирравосуђа и њихова йримена резулитираће усклађеним кривичним иравом. Ови докумениши су израђени у складу са ЕЦХР-ом и релеваниином судском йраксом Евройског суда за људска йрава која обећава већу иниееграчију два гілавна евройска систиема законодавстива.

Кључне речи: мере ӣравичног суђења, Сйокхолмски йрогррам, йраво на информисање, иррейиостивка невиностии.

Датум пријема рада: 17.05.2017. 

Прегледни чланак

doi:10.5937/zrpfns51-15493

Мр Драг̄ана Ч. Васиљевић

Минисииарсииво унуйращњих иоослова Рейублике Срйске

milijevic983@gmail.com

\section{ПРАВНА ПРИРОДА „ОРГАНИЗАЦИЈСКЕ ВЛАСТИ НАД ДЈЕЛОМ““ (ORGANISATIONSHERRSHAFT)}

Сажжейак: изврщетье кривичних дјела у случају орг̄анизачијске властии над

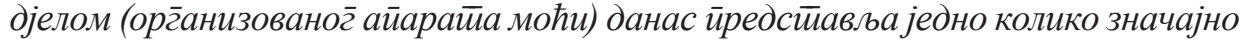

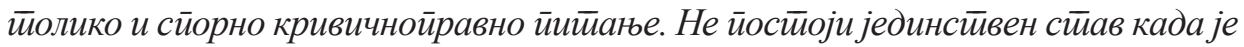

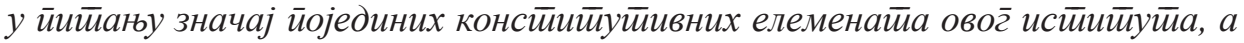

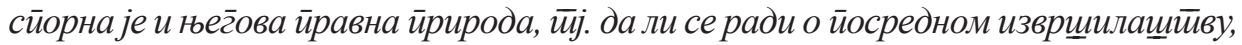
саизвриилашииву или йодсіирекаваюу. Најисиравнијим се смайрају схвайања која г̄а одређују као облик йосредног̄ извршилащӣва. Ауйор у чланку анализира

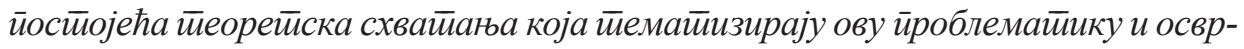
ће се на мјестио и значај овог инсииитиуйа у савременом кривичном ирраву.

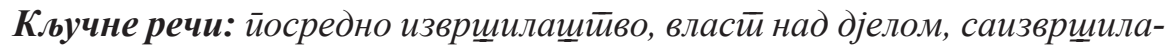
щимиво, йодсиирекавање, кривично ирраво.

\section{1. УВОДНЕ НАПОМЕНЕ}

Плуралитет лица у остварењу кривичног дјела представља једно од најзамршенијих питања кривичног права и одувијек је било предметом доктринарних расправа. Ова, динамична област, у свом развоју нужно је изњедрила и нове, понекад и атипичне, кривичноправне конструкције са циљем да се што прецизније одреди мјесто и улога појединца у остварењу кривичног дјела. Прије почетка изучавања једне од њих напоменућемо само да се учешће више лица у остварењу кривичног дјела јавља у виду извршилачког и саучесничког учешћа, приликом чега се извршилачко учешће надаље класификује на појединачно извршилаштво, саизвршилаштво и, за „Организацијску власт над дјелом“ најзначајније: посредно извршилаштво. ${ }^{1}$

${ }^{1}$ Највише схватања о извршењу кривичног дјела проналази се у њемачкој кривичноправној теорији, а као најдоминантније се истиче Роксиново (Roxin) промишљање о 
Промишљање о организацијској власти над дјелом настало је 1963. године у фундаменталном Роксиновом (Roxin) дјелу „Извршење и контрола над радњом извршења" (Täterschaft und Tatherrschaft) ${ }^{2}$, док је овај концепт детаљније разрађиван од стране Шредера (Friedrich-Christian Schroeder) 1965. године у његовој тези „Извршилац иза извршиоца“ (der Täter hinter dem Täter) ${ }^{3}$. Најједноставније речено, у питању је власт над вољом која почива на темељима организованог апарата моћи. ${ }^{4}$ Иако је настало прије више од шездесет година, кривичноправна догматика посебну пажњу овој проблематици посвећује и данас; могло би се рећи за нијансу више. Структурално се разликује од других појавних облика (посредног) извршилаштва, а кривичноправна догматика је и даље сукобљена око његове правне природе: да ли је у питању уопште извршилачко учешће (посредно извршилаштво и саизвршилаштво) или је ријеч о саучесништву - подстрекавању. ${ }^{5}$

извршилаштву утемељено на „Власти над дјелом“ (њем. Tatherschaftslehre). Како се извршилаштво може испољити у облику непосредног и посредног извршилаштва, односно саизвршилаштва, тако и ова теорија према Роксину може да се јави као „власт над радњом извршења“ (Einhandlungsherrschaft) у случају непосредног извршилаштва, као „функционално извршилаштво“ (funktionale Tatherrschaft) у случају саизвршилаштва, и као „власт над снагом воље“ (Willensherrschaft) у случају посредног извршилаштва. Посредно извршилаштво се, опет, јавља у неколико констелација. Ријеч је посредном извршилаштву у случају када средство не испуњава биће кривичног дјела, у случају када средство поступа у складу са законом, посредном извршилаштву на основу присиле, затим у случају када средство поступа у заблуди, у случају неспособности или смањене способности средства за кривицу, и посредном извршилаштву у случају тзв. организацијске власти (Organisationsherrschaft), вид. Поглавље Ц у Роксиновом уџбенику: Claus Roxin, Strafrecht Allgemeiner Teil (Band II Besondere Erscheiunungsformen der Straftat), Verlag C. H. Beck, München 2003, 19 - 55. О извршилаштву такође вид. /Heine/ Adolf Schönke, Horst Schröder, Strafgesetzbuch Kommentar, Verlag C.H. Beck, München 2010, 483 - 484.

2 Полазна основа за развој овога института је било Роксиново приступно предавање одржано 5. фебруара 1963. године у Готингену (Göttingen), Claus Roxin, „Organizationsherrschaft und Tatentschlossenheit“, Zeitschrift für Internationale Strafrechtsdogmatik 7/2006, 293. Роксин је настојао да развије теорију чија примјена би омогућила да нацистички лидери као што је био Адолф Ајхман (Adolf Eichmann) буду одговорни као извршиоци за злочине почињене у оквиру њихових режима.

${ }^{3}$ Вид. С. Roxin, $19-55$.

${ }^{4}$ Willensherrschaft kraft organizatorischer Machtapparate, вид. Igor Bojanić, Počiniteljstvo kao vlast nad djelom, Kaznenopravno kriminalistička biblioteka „Vladimir Bayer“, Zagreb 2003, 75 .

${ }^{5}$ Вршење кривичних дјела путем организованог апарата моћи значајно је са аспекта индивидуалне кривичне одговорности. Овај облик извршилаштва представља један од начина одређивања кривичне одговорности у, како то истиче Фогел (Vogel), „системском“ контексту. Анализирајући дванаест модела одређивања кривичне одговорности у „системском“ моделу организовани апарат моћи означен као „нормативни“ модел представља опозит „натуралистичком“ моделу, вид. Joachim Vogel, „How to Determine Individual Criminal Responsability in Sistemic Contexts: Twelve Models“, Defense Sociale Revista 02/16, 154 - 155. 


\section{2. ОСНОВНА ОБИљЕЖЈА „ОРГАНИЗАЦИЈСКЕ ВЛАСТИ НАД ДЈЕЛОМ“}

Кривичноправни институт посредног извршилаштва својствен је констелацијама гдје на страни непосредног извршиоца увијек постоје околности које искључују да он, иако предузима радњу извршења кривичног дјела, буде уједно и његов извршилац. За разлику од овога, код кривичноправне фигуре извршилаштва кроз организовани апарат моћи ријеч је о уникатној правној конструкцији изграђеној по принципу непосредно извршилаштво + посредно извршилаштво, мада су у кривичном праву заступљена и другачија схватања. ${ }^{6}$ Непосредно извршилаштво у принципу припада појединцу који извршава налоге или наређења, док се као посредни извршилац јавља тзв. „организатор“ или наредбодавац који својствено теорији „Власти над дјелом“, господари његовим извршењем ${ }^{7}$. Код ове констелације наредбодавац је „извршилац иза извршиоца“" и има испод себе организовани апарат моћи којим се користи за извршење кривичног дјела. Присутан је специфичан начин дјеловања апарата моћи; јамчи се остварење наредби, без обзира на то ко ће конкретну наредбу извршити; 8 организатору на располагању стоји тзв. „послушна машинерија“.9 Да би се за овакве случајеве могло устврдити да представљају посредно извршилаштво оваплоћено у виду организованог апарата моћи, потребно је да буду остварени одређени услови. Систематизацију елемената је направио прије свега Роксин према коме та организација мора, као прво, имати чврсту хијерархијску структуру, затим чланови организације морају бити лако замјенљиви, и на крају организација мора макар дјелимично да дјелује изван правног поретка. ${ }^{10}$

${ }^{6}$ Поједини њемачки аутори залажу се за тзв. аутономни принцип одговорности: посредно извршилаштво није могуће у случају да је особа која предузима радњу извршења кривичног дјела кривично одговорна, о овоме вид. Thomas Weigend, "Perpetration through an Organization - The Unexpected Career of a German Legal Concept", Journal of International Criminal Justice 9/2011, 96, упор. Kai Ambos, „The Fujimori Judgment - a President's Responsibility for Crimes Against Humanity as Indirect Perpetrator by Virtue of an Organized Power Apparatus“, Journal of International Criminal Justice 9/2011, 147.

${ }^{7}$ У питању је господарење или контрола над „током догађаја“, вид. Neha Jain, „The Control Theory of Perpetration in International Criminal Law”, Chicago Journal of International Law 1/12, 171. Амбос (Ambos) с правом истиче да је за разлику од класичних случајева посредног извршилаштва код којих посредни извршилац има директну контролу над посредником, у случајевима макрокриминалитета особа из позадине контролу остварује кроз механизам организованог апарата, вид. Kai Ambos, „Täterrschaft durch Willensherrschaft kraft organisatorischer Machtapparate - Eine kritische Bestandsaufnahme und Weiterführende Ansätze“, Goltdammer's Archiv 1998, 234.

${ }^{8}$ I. Bojanić, 76.

${ }^{9}$ Вид. Владо Камбовски, Учестиво на йовеке лица во казненойо дело, Скопје 2001, 136.

${ }^{10}$ Само уколико су испуњени ови услови, руководиоци организације могу бити сигурни да ће њихова наређења бити извршена у свим околностима, вид. T. Weigend, 97. Врховни суд Перуа је у случају Фуџимори (Fujimori) навео пет услова за постојање посредног извршилаштва путем организованог апарата моћи, вид. K. Ambos, 149 - 150. Треба истаћи да се њемачки 
Чврста хијерархијска структура. Овај елемент подразумијева могућност издавања наређења лицима која се налазе на нижој разини љествице у организованом апарату моћи. Однос надређености - подређености произилази из начела хијерархије, односно безпоговорног и ефикасног извршавања наредбе. Оваквог схватања је и Ботке (Bottke), према коме је укупно криминогено понашање организованог апарата моћи засновано на томе да виши на хијерархијској љествици издају нижима упутства за извршење кривичног дјела, док у понашању колектива преовладава команда и поштовање. ${ }^{11}$ (Строга) хијерархија омогућава специфичан начин дјеловања апарата означен као „аутоматски“ ${ }^{12}$ који омогућава извршавање наредби без обзира на то ко ће непосредно предузети радњу извршења. Она омогућава доминацију над дјелом која се јавља на страни особе која се налази на врху хијерархијске љествице и која се дјелимично због овог услова не плаши да ће наредба остати неизвршена, ${ }^{13}$ али исто тако омогућава постојање посредног извршилаштва и од особе која је поступала опет по туђој инцијативи. Код посљедње наведеног је важно само да она управља макар дијелом организованог апарата моћи (на примјер једна особа управља оружаним снагама, друга полицијом, трећа обавјештајним службама и слично). Међутим, дискутабилно је да ли је овај кривичноправни институт примјенљив и на особе који се налазе нпр. на средњем нивоу у љествици командовања. ${ }^{14}$ Чињеница је да они контролишу дио организованог апарата и делегирају наређења на констелацију из које треба да произиђу извршиоци кривичних дјела и, с тим у вези, не би било оправдано одрећи им статус посредног извршиоца.

Замјенљивост (фунгибилитет). За поменуту строгу хијерархијску структуру надовезује се елемент „замјенљивости“ лица која функционишу у оквиру организованог апарата моћи. Наиме, у случајевима одбијања извршења наредбе, одустанка или немогућности да се она изврши од стране

савезни суд у пресуђеном случају „организацијске власти над дјелом“ из 1994. године користио комбинацијом Роксинових критеријума са Шредеровим (Schroeder) критеријумом спремности за извршење кривичног дјела, вид. N. Jain, 172.

${ }^{11}$ Вид. К. Ambos (1998), 228. Супротно овоме, Осиел (Osiel) је скептичан према Роксиновој привржености структуираном и хијерархијски организованом апарату који се користи за извршење кривичних дјела и сматра да су неформалне структуре моћи ефикасније средство за извршење кривичних дјела, вид. N. Jain, 194.

12 У питању је „... бесиријекорно функиионисање айарайа моћи као хијерархијски

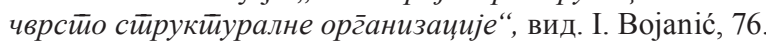

13 Овако Роксин, вид. Т. Weigend, 97.

14 У теорији су присутна мишљења према којима постоје три нивоа извршилаца код овога кривичноправног иснтитута: први и уједно највиши ниво гдје се налази извршилац који генерално планира извршење кривичних дјела (Führungstäter), средњи ниво гдје се налазе (са)извршиоци који контролишу дио организованог апарата моћи (Organisationstäter) и трећи, најнижи ниво на коме су налазе непосредни извршиоци кривичних дјела (Ausführungstäter), вид. К. Ambos, 149. 
једног лица, на његово мјесто долази неко други ко је спреман да поступи по издатом наређењу. Због тога се каже да је круг лица која представљају потенцијалне, а непосредне извршиоце кривичних дјела, уствари мноштво „точкова у строју апарата моћи“15, гдје је сваки и у сваком тренутку замјењив уколико је то неопходно у сврху успјешног остварења кривичног дјела ${ }^{16}$. Кривично дјело у сваком случају бива извршено и особа из позадине не мора нити да зна за непосредног извршиоца. Када је у питању замјењивост као један од елемената извршења кривичних дјела од организованог апарата моћи, питање је да ли се овај елемент може посматрати као одлучујући. Роксин и Шмидхојзер (Schmidhäuser) потенцирају овај критеријум ${ }^{17}$ за разлику од Херцберга (Herzberg) који, прихвата елемент „замјењивости“, али

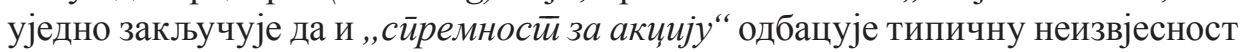
од успјеха. ${ }^{18}$ Критика критеријума замјењивости долази до изражаја и код Осиела (Osiel) према коме је она упитна у тзв. „малим организацијама“ јер се чланови не могу тако лако замијенити ${ }^{19}$. Шредер (Schroeder) такође није мишљења да замјењивост представља одлучујући елемент за заснивање

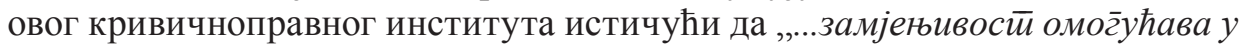

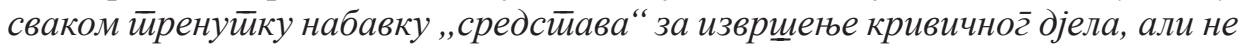
и њег̄oв одлучујући разлог̈“. ${ }^{20} \mathrm{У}$ смислу наведеног, издваја се и његов аргумент да је замјењивост у смислу одлучујућег елемента за извршење кривичног дјела кроз организовани апарат моћи упитна у случајевима посљедњих чланова у ланцу извршења, гдје најчешће изостаје друго лице које ће замијенити претпостављеног извршиоца кривичног дјела и само извршити кривично дјело. Поред замјењивости, оправдано треба издвојити и друге објективне елементе који се могу јављати и бити релевантни за извршење кривичног дјела као нпр. „безусловна сиремносй“ за предузимање радње извршења (према Шредеру представља најзначајнију карактеристику организованог апарата моћи), ${ }^{21}$ или евентуално равнодушност која се може појавити на страни непосредног извршиоца кривичног дјела. ${ }^{22}$

Дјеловање изван правног поретка. За постојање ове кривичноправне фигуре захтјева се и дјеловање изван граница правног поретка. Наиме, органи-

${ }^{15}$ Вид. В. Камбовски, 136.

16 У питању је тзв. негативна замјењивост. Поред наведеног, у пракси је присутна и тзв. позитивна замјењивост која постоји када особе из позадине из мноштва потенцијалних извршилаца бирају најквалификованије да би се на тај начин искључила могућност да кривично дјело остане неизвршено, вид. К. Ambos (1998), 228.

17 За Роксина је овај елемент најзначајнији, вид. К. Ambos (1998), 228.

${ }^{18}$ Вид. К. Ambos (1998), 228; Friedrich-Christian Schroeder, „Tatbereitschaft gegen Fungibilität“, Zeitschrift für Internationale Strafrechtsdogmatik 11/2009, 569.

${ }^{19}$ N. Jain, 194.

${ }^{20}$ Вид. F. С. Schroeder, 570.

${ }^{21}$ Вид. F. С. Schroeder, 569; К. Ambos (1998), 229.

${ }^{22}$ Овако Осиел, вид. N. Jain, 194. 
зовани апарат моћи који стоји на располагању особи из позадине увијек одступа од правила правног поретка. Он је најчешће организован у складу са правилима правног поретка, мада кривичноправна доктрина помиње и организовани апарат моћи у случају криминалних ораганизација уколико су испуњени остали услови (строга хијерархијска структура и замјењивост чланова) ${ }^{23}$. Када се говори о организованом апарату моћи утемељеном на правилима правног поретка мора бити ријечи о његовом потпуном одступању од поменутих правила. Ово због тога што наређења издата због везаности правним поретком представљају наређивање кажњивог понашања које не представља кривично дјело (тј. не може се оквалификовати као посредно извршилаштво) због вишег ранга вриједности закона чије одредбе искључују противправност кривичног дјела. ${ }^{24}$ У другом случају, само организовање оваквих организација предвиђено је као кривично дјело, а организатори одговарају по природи ствари и за сва кривична дјела која се изврше од чланова организације. Камбовски наводи примјер организовања злочиначког удружења као самосталног кривичног дјела гдје организатор одговара и за кривична дјела извршена од стране криминалног удружења уколико је организовао и руководи удружењем, уколико је присутан хијерархијски однос који исходује безусловном послушношћу у вези са издатим наредбама и уколико су кривична дјела непосредних извршилаца обухваћена генералним умишљајем. ${ }^{25}$ С тим у вези ми и не можемо у stricto sensu говорити о одступању од правног поретка у дијелу који се односи само на извршење конкретних кривичних дјела; овдје су све дјелатности (од организовања па до извршења конкретног кривичног дјела) супротне правилима правног поретка.

\section{3. ОДНОС „ОРГАНИЗАЦИЈСКЕ ВЛАСТИ НАД ДЈЕЛОМ“ И САИЗВРШИЛАШТВА}

У кривичноправној литератури нису страна схватања према којима ситуације које садржински одговарају организованом апарату моћи представљају у ствари саизвршилачко учешће. С тим у вези, саизвршилаштво

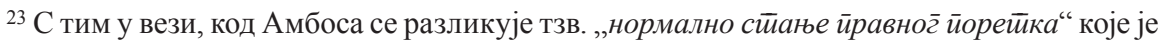
обавезно да се супротставља криминалитету и тзв. „изойаченом“ правном поретку базираном на тајном плану владе који је усмјерен ка остварењу кривичних дјела... Исто тако, ова кривичноправна фигура постоји и код апарата који се налазе у симбиози са државом као што је случај са Сицилијанском мафијом или Колумбијским картелима дроге, које према аутору нису одвојене од закона али не представљају државу, већ „пара државу“, вид. К. Ambos (1998), 243.

${ }^{24}$ Вид. I. Bojanić, 76; N. Jain, 177.

${ }^{25}$ Вид. В. Камбовски, 138. О овим елементима вид. још и Мило Бошковић, „Криминалне групе и организације“, Зборник радова Правног̄ факулиеети а у Новом Саду 1-2/2008, 300-302. О организовању злочиначких удружења упор. Драгиша Дракић, „Организовање злочиначких удружења као облик саучесништва у светлу борбе против организованог криминалитета”, Зборник радова Правног̄ факулиетейа у Новом Саду, 1/2005, 225-239. 
заступају Јешек/Вајгенд (Jescheck/Weigend), Бауман/Вебер (Bauman/Weber), Ото (Otto), и Јакобс (Jakobs). ${ }^{26}$ Јешек/Вајгенд аргументују то чињеницом да се заједништво одлуке о извршењу дјела успоставља кроз свијест вођства и извршитеља да одређено дјело или више њих треба да буду извршени у складу са датим упутствима (свијести тиреба да ,буде у складу са уйуйсиивима линије“"27, док Бауман/Вебер за постојање саизвршилачког учешћа не захтијевају постојање личних контаката и заједничког планирања; довољно

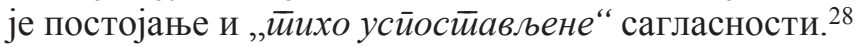

Организовани апарат моћи као начин извршења кривичних дјела не може се поистовијетити са саизвршилаштвом. У тражењу дистинкција треба поћи од елемената саизвршилаштва. Саизвршилаштво (њем. Mittäterschaft), обједињујући доступна теоријска ${ }^{29}$ и нормативна схватања, постоји када два или више лица уз свијест о заједничком дјеловању предузимају (умишљајно или нехатно) радњу извршења кривичног дјела или на други (битан) начин умишљајно остварују кривично дјело. Јасно се увиђају основни елементи овог института; ријеч је о субјективном елементу који се јавља у виду свијести о заједничком извршењу кривичног дјела и о објективном елементу који се манифестује у заједничком остварењу радње извршења или заједнички на неки други (битан) начин доприношењу остварења кривичног дјела. На субјективном плану, код (са)извршиоца кривичног дјела захтијева се постојање управљачке воље. Тражи се воља о извршењу кривичног дјела, воља да се доминира у процесу његовог извршења; појединац, да би био саизвршилац, треба да буде коаутор одлуке о дјелу и о заједничком извршењу. ${ }^{30}$ Објективна компонента (према преовлађујућој теорији „Власти над дјелом“) је прилог учесника који је такав да га ставља у позицију да он на битан, одлучујући, прворазредан начин партиципира у извршењу кривичног дјела. Код саизвршилаштва ријеч је о дјелатностима којима се битно (erheblich) доприноси извршењу кривичног дјела, и које чине да је лице носилац

${ }^{26}$ C. Roxin, 52.

${ }^{27}$ C. Roxin (2006), $294-295$.

${ }^{28}$ C. Roxin, 52.

${ }^{29}$ Саизвршилаштво је различито дефинисано и у теорији кривичног права. На примјер, оно се генерализује као самосталан облик извршилаштва који постоји „уколико вище лица заједнички изврще кривично дјело“, вид. С. Roxin, 77; /Heine/ A. Schönke; H. Schröder, 514. Додуше, могу се пронаћи и нешто другачија одређења; нпр. по Велцелу (Welzel) саизвршилаштво је „на вище људи йодијељено изврщење међусобно йовезаних сврсисходних йариијалних радњи иррема једној заједничкој одлуци о радњи“, за Маураха (Maиrach) „саизвриилачје онај који без

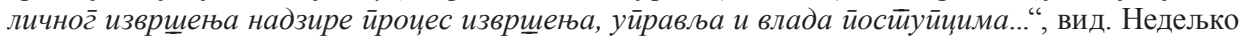
Јованчевић, Подсӣрекавање - облик саучеснищйва и самостиално кривично дело, Београд 2008, 87. По Фоглеру (Vogler) саизвршилаштво је „свјесно и вољно сарађивање у изврщењу кривичног дјела“, вид. Theo Vogler, „Versuch und Räcktritt bei der Beteiligung mehrerer an der Straftat “, Zeitschrift für die gesamte Strafrechtswissenschaft" 2/1986, 337.

${ }^{30}$ Овако Велцел, вид. Franjo Bačić, „O saizvršilaštvu“, Naša zakonitost 1/1982, 17. 
материјалне власти над дјелом. Ова радња је повезана са дјелатностима које предузимају други учесници у извршењу кривичног дјела на начин да их битно допуњује, ${ }^{31}$ заснивајући заједничку (функционалну) власт над дјелом. Оно што се предузима, иако није радња извршења, у функционалном смислу мора бити од великог значаја и вриједности за реализацију кривичног дјела. ${ }^{32}$ Ријеч је о дјелатностима без којих кривично дјело практично не би могло бити остварено, тј. дјелатностима путем којих се остварује права доминација у дјелу. Овај „кључни положај“ саизвршиоца и његове радње постојаће у случајевима када је та дјелатност, коју треба предузети, таквог значаја да би без њене реализације било онемогућено извршење кривичног дјела. Сада већ није тешко утврдити поменуту дистинкцију између организацијске власти као начина извршења кривичног дјела и саизвршилаштва.

Разлоге за негирање саизвршилаштва треба потражити превасходно на субјективном плану. Саизвршилаштво подразумијева заједничку одлуку за извршење кривичног дјела а заједничка одлука подразумијева претходни заједнички договор два или више лица и на основу тога предузимање радње извршења кривичног дјела или других дјелатности којима се остврује битан допринос његовом извршењу. То значи да сваки (са)извршилац мора бити свјестан да дјелује са осталима у извршењу кривичног дјела и мора то хтјети. ${ }^{33}$ Одлука и заједничко извршење дјела повезује саучеснике и њихове воље и доприносе у једну цјелину. Сваки учесник је заједно са другим (са)носилац ${ }^{34}$ одлуке о дјелу и о томе да заједнички изврше дјело. Овдје је веома битна заједничка „субјективна веза“, која се односи на свијест о зависности ${ }^{35}$, попуњавање својим доприносом туђих дјелатности, али и допуњавање туђим доприносом сопствене дјелатности ${ }^{36}$ у извршењу конкретног кривичног дјела. Код извршења кривичног дјела путем организованог апарата моћи заједничке одлуке о извршењу кривичног дјела нема, заједничка сагласност воља не постоји. То да непосредни извршилац кривичног дјела једноставно испуњава налоге особе из позадине не може се посматрати у свјетлу чињенице да између њих постоји заједничка одлука да изврше кривично дјело, нити да постоји заједничка субјективна веза која оправдава саизвршила-

${ }^{31}$ Наташа Делић, „Неке дилеме у вези законског појма саизвршилаштва“, Ревија за криминолог̄ију и кривично ӥраво; 3/2009, 267.

${ }^{32}$ Н. Делић, 267.

${ }^{33}$ Haro Otto, Grundkurs Strafrecht-Allgemeine Strafrechtslehre, Deutschland 2004, 21.

34 Овако Велцел, супротно Маурах, вид. Н. Јованчевић, 139,142.

${ }^{35}$ Stefan Grabow, Stefan Pohl, „Die Sukzessive Mittäterschaft und Behilfe“, JURA - Juristische Ausbildung 9/2005, 659. Оваквог схватања је Ингелфингер (Ingelfinger) према коме план о дјелу ствара зависност појединца од његових саучесника у злочину, која је мотивисана извршењем сопственог удјела у томе чину.

36 Према Геперту у смислу „сви за једног, један за све“, Klaus Geppert, „Die Mittäterschaft (25 Abs 2 StGB)“, JURA - Juristische Ausbildung 1/2011, 32; упор. H. Otto, 372. 
штво ${ }^{37}$. Овдје изостаје договор, подјела активности; нема ту нити прећутног договора (конклудентне радње) за извршење кривичног дјела, па да се призна саизвршилаштво. Извршилац кривичног дјела не може план који постоји на страни наредбодавца учинити својим. ${ }^{38}$ Узимајући у обзир напријед наведено, наредба не представља заједничку одлуку, са њом се непосредни извршилац кривичног дјела у концу само саглашава и то било због већ предочене чињенице да може бити замијењен, било због постојања безусловне спремности за извршење кривичног дјела. Заједничка одлука се јавља као фикција између осталог и из разлога што се наредбодавац и извршилац не познају, а вјероватно се никада неће нити упознати. Исто тако, међусобна свијест о зависности извршилаца код организованог апарата моћи није испољена јер не постоји конкретизација извршиоца када је у питању однос надређени подређени: ко ће то конкретно предузети радњу извршења кривичног дјела па да поменута свијест постоји? Са друге стране, није тешко уочити парадокс присутан код обрнуте ралације подређени - надређени: како допунити свој допринос доприносом туђих дјелатности, да ли то значи да подређени иницира дјелатности којима се остварује кривично дјело од стране надређеног?

И на концу, треба поменути још један аргумент који не иде у прилог саизвршилаштва: код њега је заједничка одлука која подразумијева равноправност воља хоризонтално заснована. Ова констатација се противи природи организованог апарата моћи који почива на строгој хијерархијској уређености. Издавање наређења (налога) у оваквим условима не представља ништа друго до вертикално уређене односе који не „трпе“ консензуалност, односно равноправност воља. На објективном плану треба само истаћи да недостаје већ поменуто заједничко извршење кривичног дјела, нарочито уколико се саизвршилаштво ограничи само на стадијум извршења.

\section{4. ОДНОС „ОРГАНИЗАЦИЈСКЕ ВЛАСТИ НАД ДЈЕЛОМ“ И ПОДСТРЕКАВАњА}

Извршење кривичног дјела путем организованог апарата моћи треба разграничити и од подстрекавања. За поједине ауторе ово рјешење је ближе усвајању од оног које потенцира саизвршилаштво. ${ }^{39}$ Подстрекавање представља психички утицај на главног извршиоца кривичног дјела са циљем да се наведе да донесе одлуку да се кривично дјело изврши, или са циљем да се та одлука „учврсти“. Теза о подстрекавању има утемељење у чињеници

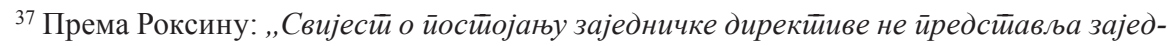
ничку одлуку“" вид. С. Roxin, 52.

${ }^{38}$ Супротно Ото, вид. C. Roxin, 52.

${ }^{39}$ Вид. С. Roxin, 54.
} 
да извршилац наредбе не може бити истовремено и средство у рукама наредбодавца. ${ }^{40}$ У питању је потпуно поштовање принципа аутономне одговорности што значи да непосредни, кривично одговорни извршилац није ничије средство. Поводом наведеног, Рензиковски (Renzikowski) истиче да појам организацијске власти над дјелом није спојив са поменутим начелом аутономије, те констатује да је замјењивост хипотетичка категорија на којој се не може засновати владање над средством. Надаље, Херцберг је експлцитан у томе да су њемачки заповједници (Хитлер, Хајмлер) издавањем наређења починили убиства, али не као извршиоци, већ као подстрекачи. ${ }^{41}$

У прилог чињеници да извршење кривичних дјела од стране организованог апарата моћи не треба третирати као подстрекавање треба навести и то да само подстрекавање не би могло у потпуности да изрази праву одговорност налогодавца која је у првом плану, а не акцесорне природе. Овдје налогодавац учествује у своме дјелу, а не у дјелу другога. Другим ријечима, иако се подстрекач означава као „интелектуални творац“кривичног дјела, он је учесник у кривичном дјелу другога, односно кривично дјело не жели као своје. Његови поступци су усмјерени ка стварању или учвршћивању одлуке код подстрекнутог да изврши конкретно кривично дјело. Јасно је да приликом вршења кривичних дјела од организованог апрата моћи налогодавац не учествује у радњи извршења али он на други начин остварује „власт над дјелом“, путем већ поменутог организованог апрата моћи. У прилог томе да је он тзв. „централна фигура“ говори и један од назива читавог концепта: „Извршилац иза писаћег стола“ (Schreibstäter), односно шаљива Роксинова опаска да нико не познаје „Подстрекача иза писаћег стола““ ${ }^{42}$ И на концу, можда би овде могао стајати још један аргумент у прилог извршилачког а не саучесничког (подстрекачког) ангажмана налогодавца, а он би био прихватљив у зависности од сложености организованог апарата моћи: чињеница да налогодавац у таквим случајевима чак нити оквирно не познаје потенцијалног извршиоца нити констелацију из које он долази ${ }^{43}$.

\section{5. КОНЦЕПТ „ОРГАНИЗАЦИЈСКЕ ВЛАСТИ НАД ДЈЕЛОМ“ И ЮЕГОВА ПРИМЈЕНА У САВРЕМЕНОМ КРИВИЧНОМ ПРАВУ}

Концепт организованог апарата моћи, поред њемачког правосуђа и латиноамеричких земаља које су под директним утицајем њемачке кривично-

${ }^{40}$ Вид. I. Bojanić, 78.

${ }^{41}$ Вид. C. Roxin, 54.

${ }^{42}$ Claus Roxin, „Bemerkungen zum Fujimori-Urteil des Obersten Gerichtshofs in Peru“, Zeitschrift für Internationale Strafrechtsdogmatik 11/2009, 566.

${ }^{43}$ Слично Роксин, вид. C. Roxin, 47. 
правне доктрине препознат је и у међународном кривичном праву ${ }^{44}$. Ваља подсјетити да је он и креиран управо због процесуирања најтежих кривичних дјела којима се повређују човјечност и друге вриједности заштићене међународним правом. Тако је још поводом случаја Ајхман констатовано да посебан облик одговорности почива на чињеници да организација има своје дијелове гдје сваки од њих мора радити заједно са циљем да се постигне одређени резултат, док читава организација дјелује под дирекцијом човјека из позадине, којег исправно треба означити као „криминални ум“ 45 .

Када је ријеч о савременом међународном кривичном праву, треба истаћи да су под утицајем теорије власти над дјелом креирана и рјешења која се примјењују у пракси међународних кривичних судова. Тачније, Римски статут у чл. 25. предвиђа облике учешћа у остварењу кривичног дјела, из-

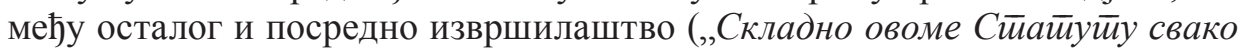
је кривично одг̄оворан и йодложан кажнавању за кривично дјело из надле-

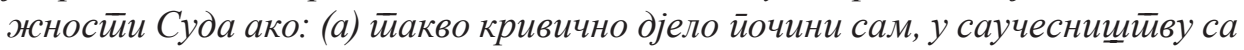

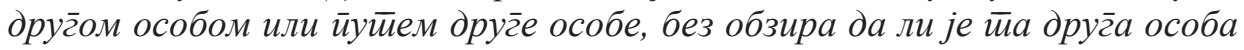
сама кривично одг̄оворна...") 46 . Без претензије за детаљнијом елаборацијом рећи ћемо само да је претресно вијеће Међународног кривичног суда пледирало за, и прихватило Роксинову теорију у случајевима Лубанга (Lubanga) и Катанга (Katanga) у интерпретацији чл. 25 (3)(a) Статута. Од значаја је став изречен у погледу првонаведеног у коме је потврђено да се контрола над директним извршиоцем може такође остварити путем организације и да су такви случајеви за међународно кривично право релевантнији. ${ }^{47}$ Поред овога, потенцирање организованог апарата моћи као посебног облика одговорности у пракси Међународног кривичног суда за бившу Југославију уоча-

${ }^{44} \mathrm{O}$ овоме и кривичноправним институтима у међународном кривичном праву вид. чланак Kai Ambos, „Remarks of the General Part of International Criminal Law“, Journal of International Criminal Justice 4/2006, 660 - 673.

${ }^{45}$ С правом Олин (Ohlin), вид. Jens David Ohlin, „The Combatant's Stance: Autonomous Weapons on the Baterfield“, International Law Studies, 1/2016, 8.

${ }^{46}$ Вид. Статут Међународног кривичног суда у Риму (Rome Statute of the International Criminal Court), ступио на снагу 01.07.2002. године, преузето дана 26.04.2017. године са сајта https://www.icc-cpi.int/nr/rdonlyres/ea9aeff7-5752-4f84-be94-0a655eb30e16/0/rome_statute_english.pdf. Статут међународног кривичног суда за бившу Југославију прихвата монистички модел извршилаштва („Особа која је йланирала, йодсиирекавала, наредила, иочинила или на друг̄и начин йомог̃ла и йодржала йланирање, йрийрему или изврщење неког̄ од кривичних дјела наведених у..."), вид. Статут Међународног кривичног суда за бившу Југославију (Statute of the International Criminal Tribunal for the Former Yugoslavia), ступио на снагу 25.05.1993. године, преузето дана 26.04.2017. године са сајта http://www.icty.org/x/file/Legal\%20Library/ Statute/statute_sept09_bcs.pdf. О општим облицима одговорности у Римском статуту вид. Бранислав Ристивојевић, „О општим облицима кривице у Римском статуту”, Зборник радова Правног̄ факулиетей у Новом Саду, 1/2008, 627-645.

${ }^{47}$ Вид. Elies van Sliedregt, Individual Criminal Responsability in International Law, Oxford University Press 2012, 87. 
ва се у издвојеном мишљењу судије Шомбурга (Schomburg) у случају Гучамбитси (Gucambitsi). Међутим, покушај увођења посредног извршилаштва није наишао на адекватан одазив; са једне стране због тога што је у пракси заступљен концепт Удруженог злочиначког подухвата, док је са друге стране изостало детаљније испитивање и објашњење посредног извршилаштва. ${ }^{48}$

На крају, значајно је истаћи и да је пресуда бившем перуанском предсједнику Фуџимори (Fujimori) утемељена на посредном извршилаштву путем организованог апарата моћи ${ }^{49}$. Суд је у овом случају вођен Роксиновим концептом ${ }^{50}$ потврдио пет елемената који утемељују кривичну одговорност на основу организованог апрата моћи и то: постојање хијерархијски устројене организације (основни услов), кривично одговоран командант као индиректини извршилац, одијељеност организације од права (дјеловање ван правног поретка), замјењивост и постојање непосредног извршиоца кривичног дјела (посебни услови). ${ }^{51}$ Треба истаћи да се примјењени концепт организованог апрата моћи у овом случају показао корисним за процесуирање високо рангираних извршилаца кривичних дјела.

\section{6. ЗАКЉУЧАК}

Концепт „Организацијске власти над дјелом“ иако настао прије више од пола вијека и данас је предмет бројних расправа. Јасно је да кривичноправна теорија није јединствена у погледу заснивајућих елемената овога института (строга хијерархија, замјењивост, дјеловање ван правног поретка). Прије свега, видљиво је да је овај концепт примјењив како у државним тако и у вандржавним структурама. Исто тако, треба се сагласити и са чињеницом да је примјењив и на средњем нивоу руковођења. Надаље, исправним се чине ставовови да замјењивост сама за себе може само једним дијелом да одговори захтјевима за постојање овог кривичноправног института; „инстант“ замјењивост није увијек могуће остварити, то може бити читав процес, док у неким случајевима фунгибилност није нити могућа. С тим у вези, она се само у комбинацији другим елементима, превасходно спремношћу за извршење кривичног дјела, може означити као један од заснивајућих елемената посредног извршилаштва у смислу концепта организованог апарата моћи.

Неспорно је да лице које врши кривично дјело из позадине користећи свој положај у систему (државне) власти, замјењивост лица која се налазе

${ }^{48}$ Вид. N. Jain, $180-181$.

49 У периоду његове владавине вршени су злочини против човјечности и друга кривична дјела за што је на крају и осуђен на казну затвора од 25 година. О овоме детаљније вид. К. Ambos, 137 - 158.

${ }^{50}$ Аутор говори о четири услова, о овоме вид. С. Roxin (2009), 565.

${ }^{51} \mathrm{~K}$. Ambos, (фус - нота 11). 
на нижим положајима у хијерархијској љествици и њихову спремност на извршење кривичног дјела, треба да буде кривично одговорно. Намеће се питање како квалификовати његову дјелатност, а самим тим одредити „праву мјеру“ одговорности. Најзаступљенија су схватања да је у питању посредно извршилаштво, иако у свом атипичном облику, јер се, за разлику од класичних случајева посредног извршилаштва, ради и о кривично одговорном непосредном извршиоцу. Тезу према којој се ради о саизвршилачком учешћу би требало одбацити због недостатка субјективног елемента, тј. заједничке одлуке да се изврши кривично дјело, која подразумијева равноправност воља и хоризонталну повезаност. Нити један поменути елемент не може се примијетити у случају „Организацијске власти над дјелом“. Надаље, промишљања која потенцирају саучесништво - подстрекавање, не одражавају на прави начин учешће особе из позадине; он учествује у своме кривичном дјелу, а не у туђем. С тим у вези прихватљива је констатација да подстрекавање не би могло у потпуности да изрази праву одговорност налогодавца која је у првом плану, а не акцесорне природе.

Што се тиче међународног кривичног права прихватање концепта „Организацијске власти над дјелом“ је селективно. Међународни кривични суд је овај концепт прихватио; прије свега кроз одредбе Статута које познају кривичноправну фигуру посредног извршилаштва, а затим и кроз своју праксу. Са друге стране не примјећује се да Међународни кривични суд за бившу Југославију познаје концепт „Организацијске власти над дјелом“ или га користи. Он је потиснут од стране широко заступљеног концепта „Удруженог злочиначког подухвата“" и помиње се само у случајевима издвојених мишљења, а као један од главних аргумената изостанка примјене ове кривичноправне фигуре издваја се неусаглашеност и њена критика у Њемачкој, земљи из које потиче.

На крају, треба истаћи да, иако изазива бројне полемике, концепт „Организацијске власти над дјелом“ можда на најбољи начин обезбјеђује процесуирање извршилаца у правилу најтежих кривичних дјела у случајевима када се они не јављају као непосредни предузимачи радње извршења. Правној природи њиховог учешћа не одговара одговорност за подстрекавање зато што не учествују у дјелу другога. Они дјело желе као своје, али не предузимају радњу извршења кривичног дјела, већ предузимају другу дјелатност која на одлучујући начин доприноси његовом извршењу. Међутим, други извршиоци (на нижем нивоу хијерархијске љествице) не дјелују хоризонтално са њима, прије свега у смислу заједничке одлуке и плана да се изврши кривично дјело, па се не може говорити нити о саизвршилаштву. Ипак остаје чињеница да су наредбодавци и извршиоци наређења подједнако значајни, односно кључни за системско остварење кривичног дјела. Стога се као једино исправно рјешење издваја додуше атипично посредно извршилаштво код кога, иако је ријеч о кривично одговорном непосредном извршиоцу, особу из позадине и његова дјела ваља квалификовати као посредног извршиоца. 
Dragana Č. Vasiljević, LL.M.

The Republic of Srpska Ministry of the Interior milijevic983@gmail.com

\title{
Legal Nature „Organizational Power over the Act“6 (Organisationsherrshaft)
}

\begin{abstract}
The commission of criminal offenses in the case of organizational power over the offense (organized apparatus of power) today represents one how important the issue is so dogmatic of criminal law. In criminal law there is no unified position when it comes to the importance of the individual constituent elements of this Istituti, a controversial and its legal nature, ie. whether it is the indirect perpetration, incitement or complicity. The most correct ideas define it as a form of indirect perpetration. The author analyzes the existing theoretical concepts that deal with this issue and refers to the place and importance of this institution in modern criminal law.
\end{abstract}

Keywords: indirect perpetration, control over the offense, complicity, incitement, criminal law.

Датум пријема рада: 27.10.2017. 
Прегледни чланак

339.923:061.1EEU(497.11)

doi:10.5937/zrpfns51-14472

Daniel Haitas, Teaching Fellow and Ph.D. Student

University of Debrecen

Faculty of Law

Géza Marton Doctoral School of Legal Studies

danielhaitas@gmail.com

\section{AN OVERVIEW OF THE EURASIAN ECONOMIC UNION AND ITS RELATIONSHIP WITH SERBIA ${ }^{1}$}

Abstract: In addition to the European Union, other regional integration projects have arisen in different parts of the world. One prominent example of this is the Eurasian Economic Union (EAEU), which seeks to reintegrate the former Soviet space. It includes among its members Armenia, Belarus, Kazakhstan, Kyrgyzstan, and Russia. To a certain extent the EAEU draws inspiration from the European Union, seeing it as model it can emulate and from which it can learn, where appropriate. The EAEU is open to new members and also seeks partners, including in Europe. An example of this is Serbia, which has expressed interest in signing a free trade agreement with EAEU. From a purely legal point of view, this may be possible, as it is not prohibited by Serbia's SAA. However, such a development may also have its problematic aspects, which includes Serbia's obligations if it becomes a fully-fledged member of the European Union and the nature of the Common Commercial Policy (CCP).

Keywords: Regional Integration, Eurasian Economic Union, European Union, Serbia, Free Trade Agreement.

\section{INTRODUCTION}

The phenomenon of regionalization can be said to be one of defining and vital characteristics of international relations in the modern era. ${ }^{2}$ The European Union has been perhaps the greatest example of a supranational regional integra-

\footnotetext{
${ }^{1}$ The paper was created within the framework of programmes aiming the increasing of quality of lawyer education (IX - 14/6/2/2017. contract number) (Ministry of Justice, Hungary).

${ }^{2}$ Zhenis Kembayev, "Regional Integration in Eurasia: The Legal and Political Framework", Review of Central and East European Law, 41/2016, 158.
} 
tion process in modern times. It has seen a vast area of continental Europe come together and create common institutions, laws, structures, borders, courts, and so on. The model of the EU has served as an inspiration for other such projects around the world, such as the Eurasian Economic Union (EAEU), which came into being in 2015. It has been explicitly stated and repeated that the EAEU seeks, to a certain extent, to emulate the EU in the post-Soviet space, claiming to learn from the successes and mistakes of the latter. The EAEU can then be seen as a parallel structure literally being created and formed on the borders of the European Union, which purports to mirror it in certain aspects. Here there shall be a survey of the background to the formation of the Eurasian Economic Union, as well as an overview of its institutional and legal structure. In addition, Serbia's relations to the EAEU shall also be examined. Due to various historical, cultural and geopolitical factors, Serbia, despite its push towards European Union integration, has strong connections to the states to the East of the EU, particularly Russia. These connections manifest themselves in various ways, one of which is the attempt to pursue a multi-vector foreign policy, which includes seeking to establish a meaningful and tangible relationship with the EAEU. The article shall attempt to examine the basic contours and aims of this relationship, and the realistic possibilities for its deepening and expansion in the context of Serbia's EU candidate status and membership aspirations.

\section{BACKGROUND TO THE FORMATION OF THE EURASIAN ECONOMIC UNION}

With the collapse of the Soviet Union, a single, deeply integrated economic, political and institutional legal space was separated into 16 different states. ${ }^{3}$ Prior to the creation of the Eurasian Economic Union there had been various attempts at forming international organizations in order to reintegrate this post-Soviet space, the first being the Commonwealth of Independent States. ${ }^{4}$ The CIS, though helping to maintain certain links between former Soviet territories, through such mechanisms as the mobility of labour and visa-free travel, was unable to put forward a clear project for an integrated political and economic community. ${ }^{5}$ It is generally acknowledged that the modern thrust towards Eurasian ${ }^{6}$ integration

${ }^{3}$ Canan Atligan, et. al., "The Eurasian Union: An Integration Project Under the Microscope", Konrad Adenauer Stiftung International Reports, 2/2014, 8, http://www.kas.de/wf/doc/kas_36785544-2-30.pdf?140207134233, 10 June 2017.

${ }^{4}$ Ibid.

${ }^{5}$ Richard Sakwa, "Eurasian Integration: A Project for the 21st Century", The Eurasian Project and Europe: Regional Discontinuities and Geopolitics (eds. David Lane and Vsevolod Samokhalov), Hampshire, 2015.

${ }^{6}$ The terms "Eurasia" itself is open to different interpretations and definitions, based on different geopolitical preconceptions. Speaking in terms of purely physical geography, it may be 
began with a speech made in 1994 by Kazakh President Nursultan Nazarbayev at the Lomonosov Moscow State University. ${ }^{7}$ Following this, in 1995 the Russian Federation, Belarus and Kazakhstan signed an Agreement on the Customs Union, the aim of which was to remove trading barriers and encourage the economic integration of these states. ${ }^{8}$ Later came the Eurasian Economic Community, formed in 2000 by Belarus, Kazakhstan, Kyrgyzstan, Russia, Tajikistan and Uzbekistan, the aim of which was promote the creation of a single economic space and customs union among these signatory states. ${ }^{9}$ Next, The Eurasian Customs Union was formed in 2010, its original members being Belarus, Kazakhstan and Russia, with it at the time being seeing as the foundation stone for a future "Eurasian Union." 10 After, the Single Economic Space or Eurasian Economic space came into being in $2012 .{ }^{11}$

It is undeniable that Russia has provided the main impetus and force behind attempts to reintegrate the post-Soviet space..$^{12}$ Russian President Vladimir Putin himself has described the collapse of the Soviet Union as "the biggest geopolitical catastrophe of the century". ${ }^{13}$ In 2011, President Putin published an article in Izvestia where he set out his vision for a Eurasian Union. Drawing explicitly from the example of the European Union, he stated that "It took Europe 40 years to move from the European Coal and Steel Community to the full European Union. The establishment of the Customs Union and the Common Economic Space is proceeding at a much faster pace because we could draw on the experience of the EU and other regional associations. We see their strengths and weaknesses. And

defined as the landmass between the Atlantic and the Pacific oceans. In terms of geopolitics, it usually refers to the lands of the former Soviet Union, excluding the three Baltic states. See Kadri Liik, Introduction: Russia's pivot to (Eur)asia, Russia's Pivot to Eurasia, European Council on Foreign Relations, 2014, 6, http://www.ecfr.eu/page/-/ECFR103_RUSSIA_COLLECTION_290514_ AW.pdf, 10 June 2017.

${ }^{7}$ Eurasian Economic Commission, Eurasian Economic Integration: Facts and Figures, 2015, 6, http://www.eurasiancommission.org/en/Documents/broshura26_ENGL_2014.pdf, 11 June 2017.

${ }^{8}$ Ibid.

${ }^{9}$ Georgios L. Vousinas, "Eurasian Economic Community: Towards Integration. Economic Challenges and Geostrategic Aspects", Modern Economy, 5/2014, 951, http://dx.doi.org/10.4236/ me.2014.59088, 12 June 2017.

${ }^{10}$ Iana Dreyer and Nicu Popescu, The Eurasian Customs Union: The economics and the politics, European Union Institute for Security Studies: Brief Issue, March 2014, 1, http://www. iss.europa.eu/uploads/media/Brief_11_Eurasian_Union.pdf, 12 June 2017.

${ }^{11}$ Rilka Dragneva and Kataryna Wolczuk, The Eurasian Economic Union: Deals, Rules and the Exercise of Power, Chatham House, May 2017, 4, https://www.chathamhouse.org/sites/files/ chathamhouse/publications/research/2017-05-02-eurasian-economic-union-dragneva-wolczuk. pdf, 13 June 2017.

12 Zhenis Kemayev, "The Court of the Eurasian Economic Union: An Adequate Body for Facilitating Eurasian Integration?", Review of Central and Eastern European Law, 41/2016, 343.

${ }^{13}$ Claire Bigg, Was Soviet Collapse Last Century's Worst Geopolitical Catastrophe?, April 29 2005, RadioFreeEurope Radio Liberty, http://www.rferl.org/a/1058688.html 20 June 2017. 
this is our obvious advantage since it means we are in a position to avoid mistakes and unnecessary bureaucratic superstructures."14 Furthermore, drawing again from the example of the EU, he stated that, "In fact, we are adapting the experience of the Schengen Agreement that benefits Europeans as well as everyone who comes to work, study, or holiday in the EU." 15 Furthermore, in Putin's stated vision of Eurasian Union, the creation of such a union is seen as a stepping stone for a greater integration project with the European Union, “...take the two largest associations on our continent - the European Union and the Eurasian Union currently under construction. In building cooperation on the principles of free trade rules and compatible regulation systems they are in a position to disseminate these principles, including through third parties and regional institutions, all the way from the Atlantic to the Pacific Oceans. They will thus create an area that will be economically harmonised, but that still will remain diverse when it comes to specific mechanisms and management solutions." 16

On May 292014 the Treaty on the Eurasian Economic Union was signed in Kazakhstan, and on January 12015 it came into force. ${ }^{17}$ Upon the signing of the Treaty, President Putin declared that "Today we are creating a powerful, attractive center of economic development, a big regional market that unites more than 170 million people." 18 The member states of the EAEU now include the Republic of Armenia, the Republic of Belarus, the Republic of Kazakhstan, the Kyrgyz Republic, and the Russian Federation. ${ }^{19}$

\section{STRUCTURE AND INSTITUTIONS OF THE EURASIAN ECONOMIC UNION}

The Preamble of the Treaty on the Eurasian Economic Union sets out the guiding principles of the organization and itsraison d'être, and it is justified to quote it at length. ${ }^{20}$ It states that, "guided by the principle of the sovereign equality of states, the need for unconditional respect for the rule of constitutional rights

14 Vladimir Putin, "A new integration project for Eurasia: The future in the making”, Izvestia, October 4 2011, http://www.europarl.europa.eu/meetdocs/2009_2014/documents/d-ru/dv/ dru_2013_0320_06_/dru_2013_0320_06_en.pdf, 20 June 2017.

${ }^{15} \mathrm{Ibid}$.

${ }^{16}$ Ibid

${ }^{17}$ R. Dragneva and K. Wolczuk, 4.

${ }^{18}$ Neil Macfarquhar, "Russia and 2 Neighbors Form Economic Union That Has a Ukraine-Size Hole", The New York Times, May 29 2014, https://www.nytimes.com/2014/05/30/world/europe/ putin-signs-economic-alliance-with-presidents-of-kazakhstan-and-belarus.html?_r=1, 25 June 2017.

${ }^{19}$ Eurasian Economic Union, General Information, http://www.eaeunion.org/?lang=en\#about.

${ }^{20}$ Treaty on the Eurasian Economic Union (Courtesy Translation), http://www.un.org/en/ga/ sixth/70/docs/treaty_on_eeu.pdf, 20 June 2017. 
and freedoms of man and national, seeking to strengthen the solidarity and cooperation between their peoples while respecting their history, culture and traditions, convinced that further development of Eurasian economic integration shall serve the national interests of the Parties, driven by the urge to strengthen the economies of the Member States of the Eurasian Economic Union and to ensure their balanced development, convergence, steady growth in business activity, balanced trade and fair competition, ensuring economic progress through joint actions aimed at solving common problems faced by the Member States of the Eurasian Economic Union with regard to sustainable economic development, comprehensive modernisation and improving competitiveness of national economies within the framework of the global economy, confirming their commitment to further strengthen mutually beneficial and equal economic cooperation with other countries, international integration associations, and other international organisations, taking into account the regulations, rules and principles of the World Trade Organisation, confirming their commitment to the objectives and principles of the United Nations Charter and other universally recognised principles and regulations of international law,..."

Furthermore, Part 1, Section 1, Article 1.1-2 of the Treaty states that "The Parties hereby establish the Eurasian Economic Union ... ensuring free movement of goods, services, capital and labour within its borders, as well as coordinated, agreed or common policy in the economic sectors determined under this Treaty and international treaties within the Union" and that "The Union shall be an international organisation of regional economic integration and shall have international legal personality".

With regards to the Customs Union formed by the EAEU member states, Section VI sets out its "Principles of Functioning". Article 25 states that "1. Within the Customs Union of the Member States: 1) an internal market for goods shall be in place; 2) the Common Customs Tariff of the Eurasian Economic Union and other common measures regulating foreign trade with third parties shall be applied; 3) a common trade regime shall be applied to relations with third parties; 4) Common customs regulations shall be applied; 5) free movement of goods between the territories of the Member States shall be ensured without the use of customs declarations and state control (transport, sanitary, veterinary-sanitary, phytosanitary quarantine), except as provided for by this Treaty."

Section III, Article 8 of the Treaty sets out Bodies of the Union, which include the Supreme Eurasian Economic Council, the Eurasian Intergovernmental Council, the Eurasian Economic Commission and the Court of the Eurasian Economic Union.

Article 10.1-2 of the Treaty state that "The Supreme Council shall be the supreme Body of the Union" and that "The Supreme Council shall consist of the heads of the Member States." According to Article 11.1, "Meetings of the Supreme Council shall be held at least once a year." Article 12.1 states that "The Supreme Council shall consider the main issues of the Union's activities, define the strategy, 
directions and prospects of the integration development and make decisions aimed at implementing the objectives of the Union." According to Article 13.2, Decisions and dispositions of the Supreme Council shall be adopted by consensus." This principle is said to be an acknowledgement of the sensibilities of certain member states, who wish to safeguard their national sovereignty. ${ }^{21}$ This concern even extends to the choice of the name "Eurasian Economic Union", which reflects the conception of the organization according to certain member states. Kazakhstan's first deputy prime minister and chief negotiator BakytzhanSagintayev stated that "We are not creating a political organization; we are forming a purely economic union ... It is a pragmatic means to get benefits. We don't meddle into what Russia is doing politically, and they cannot tell us what foreign policy to pursue."'22

Article 14 states that "The Intergovernmental Council shall be a Body of the Union consisting of the heads of governments of the Member States." According to Article 15.1, "Meetings of the Intergovernmental Council shall be held as necessary, but at least twice year." Its responsibilities include, among others, ensuring implementation and control of the Treaty, as well as "international treaties within the Union and decisions of the Supreme Council"23. Additionally, the Intergovernmental Council can "consider, on the proposal of the Council of the Commission, any issues for which no consensus was reached during decision-making in the Council of the Commission." ${ }^{24}$

Articles 18.1-2 state that "The Commission shall be a permanent governing Body of the Union. The Commission shall consist of a Council and a Board" and that "The Commission shall issue decisions, dispositions and recommendations." Annex I to the Treaty states that "The basic objectives of the Commission shall be to enable the functioning and development of the Union, as well as to develop proposals in the sphere of economic integration within the Union." ${ }^{25}$ According to the Treaty, the residence of the Commission is to be in Moscow. ${ }^{26}$

According to the Treaty, in the case of conflict between the various above mentioned institutions, the Supreme Economic Council decisions prevail over those of the Intergovernmental Council and Economic Commission, while the Intergovernmental Council's decisions prevail over those of the Economic Commission. ${ }^{27}$

With regards to the Court of the Union, Article 19.1 declares that "The Court of the Union shall be a permanent judicial Body of the Union". According Chap-

${ }^{21}$ Madalina Vicari, "The Eurasian Economic Union- approaching the economic integration in the post-Soviet space by EU-emulated elements", Papers in Political Economy, 55/2016, https:// interventionseconomiques.revues.org/2823, 26 June

${ }^{22} \mathrm{~N}$. Macfarquhar.

${ }^{23}$ Art. 16.1 .

${ }^{24}$ Art. 16.2.

${ }^{25}$ Chap. 1.1.

${ }^{26}$ Art. 18.4.

${ }^{27}$ Art. 6.4. 
ter 1.2 of the Annex 2 to the Treaty on the Eurasian Economic Union, "The objective of the Court's activities shall be to ensure, in accordance with the provisions of this Statute, uniform application by the Member States and Bodies of the Union of the Treaty, international treaties within the Union, international treaties of the Union with a third party and decisions of the Bodies of the Union." Chapter 2.7-8 of the Annex 2 state the Court shall be composed of two judges from each of the respective Member States, each serving a term of 9 years. According to Chapter 2.10, "Judges shall be appointed by the Supreme Eurasian Economic Council on the proposal of the Member States." It began its operation on January $12015^{28}$ and, in accordance with Article 19.3 of the Treaty, is located in Minsk, Belarus.

According to Article 110.1 of the Treaty, the "Russian language shall be the working language of the Bodies of the Union" and Article 110.2 states that "International treaties within the Union and decisions of the Commission that are binding on the Member States shall be adopted in Russian."

\section{SERBIA AND THE EURASIAN ECONOMIC UNION}

The EAEU, like the European Union, being a multi-national international organization, is both open to new members and seeks to broaden its relations and contacts with various states throughout the world. One prominent example of this in Europe is Serbia. Despite being having the status of a candidate country for European Union membership, Serbia is firmly pursuing what may be termed as a multi-vector foreign policy, one which seeks to maintain a diverse array of friendly relations with countries that are not Member States of the EU or part of the broader Euro-Atlantic structures. A statement made by President Aleksandar Vucic at the Astana Expo 2017 clearly expresses this approach: "I think that Serbia is building a new image and a new face toward the world, not only the West, but also her in the East. I believe that our country, which has just over seven million people, which is territorially very small ... managed to occupy a very high position due to our policy of preserving independence and sovereignty and independent decision-making in foreign policy action and address." 29

One major component of this policy is Serbia's relationship with Russia, and, by extension, its desire to foster and deepen ties with the Eurasian Economic Union. This interest in cooperation with the bloc has even been publicly acknowledged by President Putin himself, who stated that work is being done in order to progress in this direction. ${ }^{30}$ The most concrete manifestation of this is the stated

${ }^{28}$ Eurasian Economic Union, Court of the Eurasian Economic Union, http://courteurasian.org/en/.

${ }^{29}$ B92, Serbia "building new image toward West and East", June 9 2017, http://www.b92. net/eng/news/politics.php?yyyy=2017\&mm=06\&dd=09\&nav_id=101509, 29 June 2017.

${ }^{30}$ B92, Serbia among countries interested in Eurasian Union - Putin, May 15 2017, http:// www.b92.net/eng/news/world.php?yyyy=2017\&mm=05\&dd=15\&nav_id=101271, 1 July 2017. 
goal of a free trade agreement between Serbia and the EAEU. ${ }^{31}$ The arguments for such an agreement include that it would further strengthen and solidify Serbia's presence in the Russian, Kazakh and Belarussian markets, while also opening markets such as Kyrgyzstan and Armenia. ${ }^{32}$ Serbian Foreign Minister Ivica Dacic said "We have free trade zone agreements with certain EAEU members but they differ in between. Now it is planned to develop and sign an integrated agreement between Serbia and the Eurasian Economic Union, that is, to perform certain unification of all these agreements. ${ }^{33}$ According to Rasim Ljajic, Minister of Trade, Tourism and Telecommunications, Serbia has a particular interest in expanding liberalization with EAEU economies in the area of different types of cotton, cheese, tobacco, sugar, poultry, wine and Fiat automobiles. ${ }^{34}$ It has also been argued that through a closer relationship with the EAEU Serbia could gain great access to Asian economies, and that there could even be opportunities as a result of cooperation with the Eurasian Development Bank. ${ }^{35}$

The Stabilization and Association agreement signed between the European Union and Serbia states that "This Agreement shall not preclude the maintenance or establishment of customs unions, free trade areas or arrangements for frontier trade except in so far as they alter the trade arrangements provided for in this Agreement." 36 In June 2016 Maja Kocijancic, European Union spokesperson for foreign and security policy, made the statement that "We have taken note that the EEU is starting negotiation with Serbia. It is clear to us that presently Serbia has three separate free-trade agreements, with Russia, Kazakhstan and Belarus, and that it hopes that it will be able to get better access to EEU markets, through the unification of the trade regime. This decision is not in contradiction with the SAA, but the EU expects Serbia not to take any steps that would lead to the violation of EU rules." 37 Later, in October Johannes Hahn, Commissioner for European Neighbourhood Policy and Enlargement Negotiations, stated on behalf of the European Commission that "During the screening part of the accession negotiations in spring

${ }^{31}$ Yaroslav Lissovolik, Serbia's FTA with the Eurasian Union: A Window of Opportunity, Valdai Discussion Club, 2 March 2017, http://valdaiclub.com/a/highlights/serbia-fta-with-theeurasian-union/, 1 July 2017.

${ }^{32} \mathrm{Ibid}$.

33 TASS Russian News Agency, Serbia plans to sign free trade zone agreement with Eurasian Economic Union, November 3 2016, http://tass.com/economy/910479, 1 July 2017.

${ }^{34}$ Karanovic \& Nikolic, Serbia To Sign An Agreement With The Eurasian Economic Union, 26 August 2016, https://www.karanovic-nikolic.com/knnews/Pages/2016/08/26/Serbia-to-sign-anAgreement-with-the-Eurasian-Economic-Union.aspx, 2 July 2017.

${ }^{35}$ TASS.

${ }^{36}$ Stabilisation and Association Agreement between the European Communities and their Member States of the One Part, and the Republic of Serbia, of the Other Part, OJ, 2010, L 28/2, Art. 39.1.

${ }^{37}$ ANSAmed, EU: Serbia's agreement with EEU not in violation of of SAA, 6 June 2016, http://www.ansamed.info/ansamed/en/news/nations/serbia/2016/06/06/eu-serbias-agreement-witheeu-not-in-violation-of-saa_e3318d9c-alcf-4ecb-b09e-c018f3763148.html, 2 July 2017. 
2014, Serbia committed to denounce all of its free trade agreements on the day of the accession to the EU. Until then, Serbia can exercise its own trade policy." 38

The issue here relates to the principle of the exclusive competence of the European Union in relation to the Common Commercial Policy (CCP), meaning that in this area that there has been a complete transference by the Member States to the EU of this particular competence. ${ }^{39}$ This principle of exclusive competence was first explicitly articulated as far back as Opinion 1/75 by the European Court of Justice, where it held to the idea of the impossibility of "concurrent powers by the Member States and the Community in this area." ${ }^{40}$ Thus Serbia, though presently free to negotiate a free trade agreement with the EAEU, would have no choice legally but to denounce such an agreement due to European Union law. However, in the meantime, it has a freedom to negotiate such an agreement, if it so wishes.

The leadership of Serbia has not seen any contradiction between its course of the country's European Union integration, and former President Tomislav Nikolic has stated that "We remain consistent in implementing European integration as our foreign policy priorities, but we give full support to other integration processes, too, such as the Eurasian Union." ${ }^{11}$ It has even been proposed that Serbia could act as "a bridge between the EU and the Eurasian Economic Union", allowing the country "to become a window for Russia into the West and for the EU to intensify and strengthen its ties in the East". ${ }^{42}$ However, the extent to which this is possible is open for debate. It may be said with some confidence that there are other factors beyond purely legal considerations when it comes to any possible future agreement between Serbia and the EAEU. Despite affirmations by various European Union officials, due to tensions between the EU and Russia over such issues as Ukraine and the sanctions imposed against the latter, it is not clear as to how positively the former will respond to a signing of a free trade agreement between Serbia and the EAEU. ${ }^{43}$ If countries like Serbia wish to establish truly substantial, stable and long-term relations with the Eurasian Economic Union

${ }^{38}$ European Parliament, Parliamentary questions: Answer given by Mr Hahn on behalf of the Commission, 12 October 2016, http://www.europarl.europa.eu/sides/getAllAnswers.do?reference $=$ E-2016-005020\&language $=$ PT, 4 July 2017.

${ }^{39}$ Paul Craig and and Grainne De Burca, EU Law: Text, Cases, and Materials, Oxford, Fifth Edition, 2011, 311.

40 Opinion 1/75, (Understanding on a Local Cost Standard) [1975] ECR 1355, 1364. Based on this Opinion and subsequent ECJ case-law, the Lisbon Treaty of 2009 incorporated into the EU Treaty structure the principle of exclusive EU competence in the field of CCP. (See Art. 3(1) TFEU).

${ }^{41}$ B92, Serbia consistent in EU bid, backs Eurasian Union, too, August 24 2016, http://www. b92.net/eng/news/politics.php?yyyy=2016\&mm=08\&dd=24\&nav_id=99005, 4 July 2017.

${ }^{42}$ Y. Lissovolik.

${ }^{43}$ Anna Nadibaidze, Will Serbia be able to balance between Russia and the West, Russia Direct, February 17 2017, http://www.russia-direct.org/analysis/will-serbia-be-able-balance-between-russia-and-west, 4 July 2017. 
while also being fully fledged members of the European Union, this can only be in the context of broader agreement and consensus between the EU and EAEU and the overcoming and solving of unresolved issues between both organizations.

As mentioned above, the Eurasian integration project has been seen as part of a greater aim of creating a common great space with the European Union, stretching "From Lisbon to Vladivostok." 44 It must be said that this seems very unlikely at this present moment in time due to the state of relations between Russia and the West. ${ }^{45}$ However, in spite of tensions in recent years, this is an ideal for which support is still expressed at the highest levels. In 2016 President Putin stated that "Along with our Chinese colleagues, we are planning to start official talks on the formation of comprehensive trade and economic partnership in Eurasia with the participation of the European Union states and China." He went on to add that "I expect that this will become one of the first steps toward the formation of a major Eurasian partnership, [...] the "greater Eurasia". ${ }^{46}$ Important voices from within the European Union have also continued to express support for such a project. German Chancellor Angela Merkel in 2016 said that "I hope that Russia would increasingly develop ties with the European economic area, finally resulting in a common economic area from Lisbon to Vladivostok." ${ }^{\prime 7}$ European Commission President Jean-Claude Juncker had also said "I have always found the idea of an integrated trade area linking Lisbon to Vladivostok to be an important and valuable objective." 48 However, at this time these thoughts and aspirations have no real likely path of implementation existing at the present moment due to the present complexity of relationships.

\section{CONCLUSION}

As seen by the statements of the Russian president, it has been explicitly acknowledged that the model of the European Union provides a major part of the inspiration for the Eurasian Economic Union model. Thus, it may in fact be argued

44 Victoria Ivanchenko, Debunking myths about the Eurasian Economic Union, Russia Direct, August 19 2016, http://www.russia-direct.org/opinion/debunking-myths-about-eurasian-economic-union, 4 July 2017.

${ }^{45} \mathrm{Ibid}$

${ }^{46}$ Danilo Elia, The Greater Eurasia, Putin's idea of Europe after Brexit, Eastwest, June 29 2016, http://eastwest.eu/en/opinions/riding-the-russian-rollercoaster/the-greater-eurasia-putin-sidea-of-europe-after-brexit, 6 July 2017.

${ }^{47}$ Sputnik News, From Lisbon to Vladivostok: Merkel Seeks Free Trade Zone Between Russia, EU, 5 June 2016, https://sputniknews.com/politics/201606051040810928-merkel-eu-russia-cooperation/, 6 July 2017.

${ }^{48}$ The Baltic Course, Lithuanian MFA: Juncker's words on EU-Russia ties his personal opinion, not EU's, 20 November 2015, http://www.baltic-course.com/eng/baltic_states/?doc=113180, 6 July 2017. 
that the creation and promotion of this integration project in the Eurasian space is in fact, to a certain extent, an example of the European Union institutional and economic model spreading beyond its own borders, acting as a prototype for integration projects in other parts of the world. As has been argued above, it is debatable as to what extent Serbia can establish truly comprehensive and meaningful relations with the Eurasian Economic Union in the long term beyond symbolism or broad statements in light of the country's European Union accession aspirations. Though the SAA does not technically preclude or prohibit legal agreements such as a free trade zone with third parties like the EAEU, in reality this would be much more difficult to implement, and even if it were achievable, the rules with regards to EU Member States trade agreements and the Common Commercial Policy would preclude a separate agreement between Serbia and the EAEU once the former attains full Member State status of the European Union. As a result, it can be said that in the long term, for countries who are or will be EU Member States and who wish to establish closer relations with the EAEU on a legal basis, the only long term possibility and solution would be the EU as a whole coming to a comprehensive understanding and agreement with the EAEU. In the present environment this does not seem very likely, but as seen above, there are those from within both the EU and EAEU who maintain a desire for a broader and expanded integrative space that would go beyond the borders of their own organizations. 


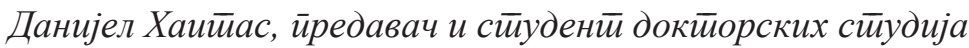
Универзийей у Дебрецину

Правни факулиетеи

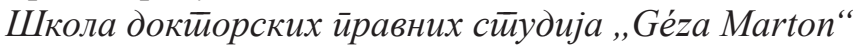

danielhaitas@gmail.com

\section{Преглед Евроазијске економске уније и њеног односа са Србијом}

Сажейак: Поред Евройске уније, у различийим деловима свейа йојавили су се друг̄и рег̄ионални иниеегррациони йројектии. Један значајан иримерак овог̄а јестие Евроазијска економска унија (ЕEУ), која иеежи да реинйегрище бивщи совјетиски иростиор. Ову унију чине следећи чланови: Јерменија, Белорусија, Казахсӣан, Кирг̄истиан и Русија. До одређене мере ЕЕУ налази инсииращију у Евройској унији, иоосмайрајући је као модел који у одређеној мери може да ойонаща и из којег може да учи. ЕЕУ је ойворена за нове чланове, а йражи и йарйнере, йоред осйалог̄ и у Евройи. Један иример овог̄ јестие и Србија, која је йоказала иниеересовање за йойиичсивање сйоразума о слободној йрг̄овини са ЕЕУ. Правно йосмайрано, йо је могууће, јер није забрањено Сйоразумом о стиабилизачији и иридруживағу који је Србија йоййисала. Међуйим, йакав иравач развоја може да има и своје

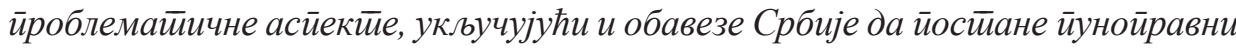
члан Евройске уније и йрироду Заједничке ӣрг̄овинске йолийике ЕУ.

Кључне речи: рег̄ионална иниеег̄рација, Евроазијска економска унија, Евройска унија, Србија, Сйоразум о слободној йрг̄овини.

Датум пријема рада: 11.09.2017. 